\title{
ECONOMICS
}

\section{AFFLUENCE AND FOOD \\ A Simple Way to Infer Incomes}

by

Kenneth W Clements

Business School

The University of Western Australia

and

\author{
Dongling Chen \\ Shanghai Municipal Authority
}

DISCUSSION PAPER 09.08 


\title{
AFFLUENCE AND FOOD \\ A Simple Way to Infer Incomes ${ }^{1}$
}

\author{
by \\ Kenneth W Clements \\ Business School \\ The University of Western Australia \\ and \\ Dongling Chen \\ Shanghai Municipal Authority
}

\begin{abstract}
$\underline{\text { Abstract }}$
Accurate and timely measures of cross-country real incomes are still a rarity. As the share of expenditure devoted to food is readily available, we use of Engel's law in reciprocal form to measure affluence. Analysis of real income data for the OECD countries indicates that this approach is viable. To recognise the role of uncertainty in the analysis, we present the results in the form of stochastic cross-country income comparisons.
\end{abstract}

\footnotetext{
${ }^{1}$ We would like to acknowledge the comments of Grace Gao and the excellent research assistance of Ze Min Hu, Shi Pei Seah and Jiawei Si. This research was supported in part by the ARC.
} 


\section{Introduction}

Economists' fascination with international income differences must go back to at least 1776 with Adam Smith's The Wealth of Nations. The most popular approach to measuring incomes in different countries is to use the purchasing-power-parity based estimates of the Penn Table. As market exchange rates are volatile, and are known to reflect the prices of nontraded goods (especially services) less than adequately, the PPP method is a substantial improvement over older approaches that make currency conversions on the basis of market exchange rates. However, the disadvantage of PPP is that as numerous matched goods and services have to be priced in many countries, it is demanding in its data requirements, so that PPP estimates can be subject to long publication delays. This paper investigates a short-cut method of measuring real incomes across countries.

Engel's law states that food has an income elasticity of less than unity, or equivalently, the share of food in the consumption basket declines with income. We use Engel's law in reciprocal form by inferring income from the value of the food share. Such an approach is consistent with Engel (1857, pp. 28-29) who writes "The poorer a family, the greater the proportion of its total expenditure that must be devoted to the provision of food", and then goes on to argue that the richer a country, the smaller the food share (Stigler, 1954). This approach has several advantages: First, as the food share is dimensionless, it can be compared across time, regions and countries, without any adjustment for differing currency values. Second, the food share is objective, not subject to great controversy and readily available for many time periods in a large number of countries. Third, the link between the food share and income as enshrined in Engel's law is well established and arguably the most widely-accepted empirical regularity in all economics. Finally, as the approach uses just one share and two parameters to make inferences regarding incomes, it is attractive in its simplicity. We analyse jointly the determinants of all elements in the consumption basket and embed Engel's law in a system-wide demand model, thereby allowing for the dependence of food share on relative prices (in addition to income). The food share, adjusted for differing relative price structures across countries, is then used to infer income.

While the basic idea of employing the food share as an inverse measure of welfare has been used by others (see, e. g., Orshansky, 1965, 1969, Van Praag et al., 1982, Rao, 1981), it seems that the approach of including food in a microeconomic demand model, and then using the price-adjusted share as the basis for inferring income, has been relatively unexplored, especially in a cross-country context. Chua (2003) made a preliminary investigation of estimating "true income" in different countries from information on the food share, but did not allow for international differences in relative prices. For related studies that deal with the CPI bias and economic performance in the US, see Costa (2001), Hamilton (2001) and Nakamura (1996). 
It is also appropriate to mention two other short-cut approaches proposed in the early literature for countries (or regions) that do not have reliable information of real incomes. The first is the use of "nonmonetary factors" such as calories consumed, infant mortality, the number of physicians, etc. Countries are ranked according to each factor, and these rankings are then averaged to yield an overall index (Bennett, 1951). The problem with this approach is that the equal weighting of indicators has no economic justification (Beckerman and Bacon, 1966). The second approach is to estimate income on the basis of easily-observed physical indicators such as the consumption of steel, energy, electricity, cement, etc. (see, e. g., Beckerman and Bacon, 1966, Erlich, 1969, and Janossy, 1963). The basic idea lying behind this approach is a type of reciprocal demand relation that excludes the usual relative price term. For those countries that have all the required data, income is regressed on the consumption variable and then the estimated relationship is extrapolated to yield income estimates for other countries. ${ }^{2}$ Heston (1973) is critical of this approach as it tends to (i) give rise to large errors for low-income countries, those countries least-well endowed with realincome information; and (ii) gives rise to too little dispersion of the cross-country income distribution. On the other hand, Barlow's (1977) results are more favourable to the physical indicator approach. ${ }^{3}$

The next two sections of the paper set out the basic analytical relationships between food consumption, income and prices. In Sections 4 and 5 these relationships are embedded in a system-wide demand model, which is then essentially inverted to solve for income. This leads in Section 6 to what we call "stochastic cross-country income comparisons" in the form of probability distributions that compare incomes for each country pair. These distributions reflect the uncertainty inherent in at all steps of the analysis, in the food share, the estimated parameters and incomes. Concluding comments are given in Section 7.

\section{Consumption, Income and Prices}

In this section, we set out the dependence of consumption on income and prices. As this material is well-known, the presentation will be brief. For more details, see, e. g., Theil (1975/76, 1980) or Theil and Clements (1987).

Let $\mathrm{p}_{\mathrm{i}}$ be the price of good $\mathrm{i}$ and $\mathrm{q}_{\mathrm{i}}$ be the corresponding quantity demanded. Then if there are $\mathrm{n}$ goods, $M=\sum_{i=1}^{n} p_{i} q_{i}$ is total expenditure ("income" for short), and $w_{i}=p_{i} q_{i} / M$ is the budget share of $i$. The Marshallian demand equation for good $i$ is $q_{i}=q_{i}\left(M, p_{1}, \ldots, p_{n}\right)$, or using a circumflex (“^”) to denote a proportional change (so that $\hat{\mathrm{x}}=\mathrm{dx} / \mathrm{x}$ ),

\footnotetext{
${ }^{2}$ Variations of this theme are provided by Duggar (1969), who uses money holdings instead of consumption variables, and Sahn and Stifel (2003), who use the stock of consumer durables.

${ }^{3}$ It is also worth mentioning that in the fields of economic history and economic development the link between stature and real incomes, and the degree to which the former can be inferred from the latter, has been studied; for a survey, see Steckel (1995).
} 


$$
\hat{\mathrm{q}}_{\mathrm{i}}=\eta_{\mathrm{i}} \hat{\mathrm{M}}+\sum_{\mathrm{j}=1}^{\mathrm{n}} \eta_{\mathrm{ij}}^{\prime} \hat{\mathrm{p}}_{\mathrm{j}}
$$

where $\eta_{i}$ is the income elasticity of demand for $i$ and $\eta_{i j}^{\prime}$ is the $(i, j)^{\text {th }}$ uncompensated price elasticity. If we define the change in the cost of living index as a budget-share weighted-average of the $n$ price changes, $\hat{\mathrm{P}}=\sum_{\mathrm{j}=1}^{\mathrm{n}} \mathrm{w}_{\mathrm{j}} \hat{\mathrm{p}}_{\mathrm{j}}$, then the change in real income is the excess of the change in money income change over this index, $\hat{\mathrm{Q}}=\hat{\mathrm{M}}-\hat{\mathrm{P}}$, and the Slutsky demand equation takes the form

$$
\hat{\mathrm{q}}_{\mathrm{i}}=\eta_{\mathrm{i}} \hat{\mathrm{Q}}+\sum_{\mathrm{j}=1}^{\mathrm{n}} \eta_{\mathrm{ij}}\left(\hat{\mathrm{p}}_{\mathrm{j}}-\hat{\mathrm{P}}\right),
$$

where $\eta_{i j}$ is the $(i, j)^{\text {th }}$ compensated price elasticity. In deriving this equation (2) from (1), we have used (i) the Slutsky decomposition $\eta_{\mathrm{ij}}^{\prime}=\eta_{\mathrm{ij}}-\mathrm{w}_{\mathrm{j}} \eta_{\mathrm{i}}$, and (ii) demand homogeneity, according to which $\sum_{\mathrm{j}=1}^{\mathrm{n}} \eta_{\mathrm{ij}}=0$.

Next, we note that $\hat{\mathrm{w}}_{\mathrm{i}}=\hat{\mathrm{p}}_{\mathrm{i}}+\hat{\mathrm{q}}_{\mathrm{i}}-\hat{\mathrm{M}}=\left(\hat{\mathrm{p}}_{\mathrm{i}}-\hat{\mathrm{P}}\right)+\hat{\mathrm{q}}_{\mathrm{i}}-\hat{\mathrm{Q}}$. Combining this with equation (2) then yields

$$
\hat{\mathrm{w}}_{\mathrm{i}}=\left(\eta_{\mathrm{i}}-1\right) \hat{\mathrm{Q}}+\sum_{\mathrm{j}=1}^{\mathrm{n}} \eta_{\mathrm{ij}}\left(\hat{\mathrm{p}}_{\mathrm{j}}-\hat{\mathrm{P}}\right)+\left(\hat{\mathrm{p}}_{\mathrm{i}}-\hat{\mathrm{P}}\right)
$$

If the $\mathrm{n}$ commodities are broad aggregates, it would be likely that there would only be limited substitutability between them. We thus take the utility function to be of the preference independent form, $u\left(q_{1}, \ldots, q_{n}\right)=\sum_{i=1}^{n} u_{i}\left(q_{i}\right)$, with $u_{i}(\bullet)$ the sub-utility function for good $i$, so that the marginal utility of i depends only on own consumption. This form of tastes implies that as an approximation, own-price elasticties are proportional to income elasticities and cross-price elasticities are zero,

$$
\eta_{\mathrm{ii}} \approx \phi \eta_{\mathrm{i}}, \mathrm{i}=1, \ldots, \mathrm{n}, \quad \eta_{\mathrm{ij}} \approx 0, \mathrm{i}, \mathrm{j}=1, \ldots, \mathrm{n}, \mathrm{i} \neq \mathrm{j},
$$

where $\phi$ is the reciprocal of the income elasticity of the marginal utility of income (the "income flexibility" for short). Equations (3) and (4) then imply

$$
\hat{\mathrm{w}}_{\mathrm{i}} \approx\left(\eta_{\mathrm{i}}-1\right) \hat{\mathrm{Q}}+\left(\phi \eta_{\mathrm{i}}+1\right)\left(\hat{\mathrm{p}}_{\mathrm{i}}-\hat{\mathrm{P}}\right),
$$

which shows the dependence of the budget share on income and the relative price of the good. The two parameters in equation (5) are the income elasticity and the income flexibility.

\section{Income and Food}

On the basis of the budget shares, in most countries food is the most important single commodity. Thus, in what follows we concentrate on this commodity. In this section, we analyse the relationship 
between food consumption and income, and defer a discussion of the role of its relative price until the next section.

We apply equation (5) to $\mathrm{i}=$ food and for simplicity, subsequently omit the commodity subscript. When the relative price of food is constant, this equation implies $d w \approx \beta \hat{Q}$, with $\beta=w(\eta-1)$. The marginal share of food is $\partial(\mathrm{pq}) / \partial \mathrm{M}$, which answers the question, if income rises by one dollar, what fraction of this is spent on food? As $w \eta=\partial(\mathrm{pq}) / \partial \mathrm{M}$, it follows that the coefficient $\beta$ is the excess of the marginal share over the corresponding budget share $w$. Using $\hat{x}=d(\log x)$, the above suggests a convenient way to relate food consumption and income in countries $\mathrm{a}$ and $\mathrm{b}$ is

$$
\mathrm{w}^{\mathrm{a}}-\mathrm{w}^{\mathrm{b}}=\beta \log \left(\frac{\mathrm{Q}^{\mathrm{a}}}{\mathrm{Q}^{\mathrm{b}}}\right) .
$$

Table 1 gives for 42 OECD countries in 2002 real per capita total consumption, which we interpret as $\mathrm{Q}$, and the food budget share. ${ }^{4}$ As can be seen, on the basis of $\mathrm{Q}$, Luxembourg is the richest country and Turkey the poorest, with a ratio of $30,258 / 4,882 \approx 6$, while the food budget shares range from less than 10 percent to about 30 percent. The budget share of each country can be systematically compared to that of all others via $42 \times 42$ skewed symmetric matrix $\left[w^{a}-w^{b}\right]$. The upper triangle of this matrix is given in Table 2, where countries are ordered in terms of decreasing affluence in the rows and increasing affluence in the columns. Thus, for example, moving from left to right along the first row, we compare the food budget share of Luxembourg with poorer countries that become successively less poor: The share for Turkey is 17 points above Luxembourg's, Macedonia's 22 above, etc. As the diagonal elements of this table would be all zero, these elements are suppressed. But as we move further away from where the diagonal would have been, in a north-westerly direction, countries differ more on the income scale and the budget shares differ by more. With only a few exceptions, for each pairwise comparison, the share in the poorer country is greater than that in the richer country, which is a reflection of Engel's law.

Table 3 gives the corresponding matrix comparisons of incomes, which for short we write as $\Delta \log \mathrm{Q}^{\mathrm{ab}}=\log \left(\mathrm{Q}^{\mathrm{a}} / \mathrm{Q}^{\mathrm{b}}\right)$. Table 4 contains the ratios $\Delta \mathrm{w}^{\mathrm{ab}} / \Delta \log \mathrm{Q}^{\mathrm{ab}}$, where $\Delta \mathrm{w}^{\mathrm{ab}}=\mathrm{w}^{\mathrm{a}}-\mathrm{w}^{\mathrm{b}}$. These ratios can be interpreted as "readings" on the coefficient $\beta$ in equation (6). Figure 1 shows that while there are a few outliers (associated with near zeros in the denominators for countries having very similar incomes), the distribution has a reasonable well defined median of about -0.13 . This result is confirmed by the corresponding scatter of Figure 2 . When $\beta=-0.13$, a country that is 50 percent richer than another has a

\footnotetext{
${ }^{4}$ The data are from OECD (2004). For details, see the Appendix.
} 
food budget share about 5 percentage points lower. If we only used information on the food share, we could employ this relationship in reciprocal form whereby $\Delta \log \mathrm{Q}^{\mathrm{ab}}=(1 / \beta) \Delta \mathrm{w}^{\mathrm{ab}}$ to make inferences regarding income differences. In Section 5 we extend this basic relationship to allow for the role of differences in relative prices, and demonstrate the importance of allowing for the impact of this additional factor.

Before concluding this section, it is worthwhile noting that by integration, equation (6) is consistent with the Working (1943)-Leser (1963) Engel curve, $w=\alpha+\beta \log Q$, where $\alpha$ is a constant. Figure 3 reveals that this model fits the OECD data quite well, and the least-squares estimate of the slope coefficient $\beta$ is close to the above-value of -0.13 .

\section{Modelling the Consumption Basket}

As indicated by equation (5), the change in the budget share of good $i$ is related to the change in income and under the assumption of preference independence, the change in the relative price of the good. The parameters in this relationship are the income elasticity and the income flexibility. To efficiently estimate these parameters, we need to consider the demand for all $\mathrm{n}$ goods simultaneously by jointly modeling the determinants of the consumption basket. There are a number of alternative models that could be used for this purpose including the linear expenditure system, the almost ideal demand model, the translog, etc. We choose the Florida model (Theil et al., 1989) as it is probably the most extensively applied and assessed in a cross-country context.

In this section, we reinstate the commodity subscript $\mathrm{i}=1, \ldots, \mathrm{n}$, and denote countries by $\mathrm{c}=1, \ldots, \mathrm{C}$. The Florida model is based on Working's model,

$$
\mathrm{w}_{\mathrm{i}}^{\mathrm{c}}=\alpha_{\mathrm{i}}+\beta_{\mathrm{i}} \log \mathrm{Q}^{\mathrm{c}}
$$

where $\alpha_{i}$ and $\beta_{i}$ are coefficients satisfying $\sum_{i=1}^{n} \alpha_{i}=1, \sum_{i=1}^{n} \beta_{i}=0$. If we denote the logarithm of real income in country $\mathrm{c}$ by $\mathrm{q}^{\mathrm{c}}=\log \mathrm{Q}^{\mathrm{c}}$, it can be easily shown that model (7) implies that the marginal share of good $\mathrm{i}$ takes the form $\alpha_{i}+\beta_{i} q^{* c}$, where $q^{* c}=1+q^{c}$. The Florida model supposes that (7) holds at world prices, as measured by geometric means, $\log \bar{p}_{i}=(1 / C) \sum_{c=1}^{C} \log p_{i}^{c}$. The $i^{\text {th }}$ equation of the model takes the form

$$
\begin{aligned}
w_{i}^{c}=\alpha_{i}+\beta_{i} q^{c} & +\left(\alpha_{i}+\beta_{i} q^{c}\right)\left[\log \frac{p_{i}^{c}}{\bar{p}_{i}}-\sum_{j=1}^{n}\left(\alpha_{j}+\beta_{j} q^{c}\right) \log \frac{p_{j}^{c}}{\bar{p}_{j}}\right] \\
& +\phi\left(\alpha_{i}+\beta_{i} q^{* c}\right)\left[\log \frac{p_{i}^{c}}{\bar{p}_{i}}-\sum_{j=1}^{n}\left(\alpha_{j}+\beta_{j} q^{* c}\right) \log \frac{p_{j}^{c}}{\bar{p}_{j}}\right] \\
& +\varepsilon_{i}^{c},
\end{aligned}
$$


where $\phi$ is the income flexibility (as before) and $\varepsilon_{i}^{c}$ is a zero-mean disturbance term, drawn from a multivariate normal distribution with a constant covariance matrix. The second term on the right-hand side of this equation, $\beta_{\mathrm{i}} \mathrm{q}^{\mathrm{c}}$, deals with the role of real income on the budget share of good $\mathrm{i}$, while the first term in square brackets is the relative price of the good, compared to the world relative price. When the relative price changes, the budget share changes even when the corresponding quantity demanded is unchanged; this effect is measured by the term $\left(\alpha_{i}+\beta_{i} q^{c}\right)\left[\log \frac{p_{i}^{c}}{\bar{p}_{i}}-\sum_{j=1}^{n}\left(\alpha_{j}+\beta_{j} q^{c}\right) \log \frac{p_{j}^{c}}{\bar{p}_{j}}\right]$. The second line of equation (8) deals with the substitution effect of a change in the relative price of the good; the weights employed in this relative price are marginal shares, $\alpha_{j}+\beta_{j} q^{* c}$, whereas in the first line of the equation they are budget shares, $\alpha_{j}+\beta_{j} q^{c}$. The final thing to note about the Florida model is that it holds under preference independence, so it is consistent with the analysis of Section 2 above.

We estimate model (8) using the maximum likelihood (ML) procedure set out in Theil et al. (1989) with data from the OECD (2004) for $\mathrm{n}=12$ goods listed in Table 5 and the $\mathrm{C}=42$ countries listed in Table 1. The results are given in columns 2-5 of Table 5. The largest estimate of $\beta_{i}$ (in absolute value) is for food at -0.10 , a value that is highly significant. That this value is about 25 percent lower than the estimate of this same coefficient discussed in the previous section indicates the importance of controlling for differences in the relative price of food across countries. An examination of the data reveals that this relative price tends to fall with real income per capita, so that omitting it has the effect of biasing upwards the estimate of $\left|\beta_{\mathrm{i}}\right|$ for food.

To assess the quality of the estimates, we conduct a Monte Carlo experiment that involves the following steps. First, we write model (8) for $\mathrm{i}=1, \ldots, 12$ as

$$
\mathbf{w}^{\mathrm{c}}=\mathbf{f}\left(\mathbf{X}^{\mathrm{c}}, \boldsymbol{\theta}\right)+\boldsymbol{\varepsilon}^{\mathrm{c}}
$$

where $\mathbf{w}^{\mathrm{c}}$ and $\boldsymbol{\varepsilon}^{\mathrm{c}}$ are vectors of budget shares and disturbances for country $\mathrm{c}, \mathbf{X}^{\mathrm{c}}$ is a matrix of the observed values of the independent variables and $\boldsymbol{\theta}$ is a vector of parameters. We simulate the budget vector for country c from equation (9) by (i) drawing $\boldsymbol{\varepsilon}_{\mathrm{c}}$ from a normal distribution with mean vector zero and covariance matrix equal to its data-based ML estimate; (ii) using for $\boldsymbol{\theta}$ its data-based estimate; and (iii) using the observed values of $\mathbf{X}^{\mathrm{c}}$. Repeating this for each of the 42 countries leads to 42 values of the simulated vector of budget shares, $\mathbf{w}^{\mathrm{c}(\mathrm{s})}, \mathrm{c}=1, \ldots, 42$, which are used together with the observed values of the independent variables to reestimate the model by the same ML procedure. Second, we repeat the procedure 1,000 times to yield 1,000 simulated values of the vector of estimated parameters, $\boldsymbol{\theta}^{(\mathrm{s})}, \mathrm{s}=1, \ldots, 1,000$. 
Columns 6-11 of Table 5 summarise the results in the form of the mean, RMSE and RMASE for each parameter. As can be seen, all estimates are unbiased, while the asymptotic standard errors tend to understate the sampling variability of the estimates, but not by a huge amount.

\section{Simulating Income}

In this section we draw inferences on cross-country incomes from the behavour of the food budget share after controlling the influence of the relative price. As before, we concentrate exclusively on food and drop the commodity subscript.

We return to equation (5) and write it as

$$
\hat{\mathrm{Q}}=\frac{\hat{\mathrm{w}}}{\eta-1}-\frac{(\phi \eta+1)(\hat{\mathrm{p}}-\hat{\mathrm{P}})}{\eta-1}
$$

where $\hat{Q}$ is the change in income, $\hat{\mathrm{w}}$ the change in the food budget share, $\eta$ is the income elasticity of food, $\phi$ is the income flexibility, $\hat{\mathrm{p}}-\hat{\mathrm{P}}$ is the change in the relative price of food, and where we have ignored the approximation error. This equation says that the change in income is equal to the difference between a term involving the change in the food share and a term that adjusts for the change in the relative price of food. To apply equation $\left(5^{\prime}\right)$ to countries a and $b$, we could express it as

$$
\log \left(\frac{\mathrm{Q}^{\mathrm{a}}}{\mathrm{Q}^{\mathrm{b}}}\right)=\frac{\log \left(\mathrm{w}^{\mathrm{a}} / \mathrm{w}^{\mathrm{b}}\right)}{\eta^{\mathrm{ab}}-1}-\frac{\left(\phi \eta^{\mathrm{ab}}+1\right)\left[\log \left(\mathrm{p}^{\mathrm{a}} / \mathrm{p}^{\mathrm{b}}\right)-\log \left(\mathrm{P}^{\mathrm{a}} / \mathrm{P}^{\mathrm{b}}\right)\right]}{\eta^{\mathrm{ab}}-1},
$$

where $\eta^{\mathrm{ab}}=\frac{1}{2}\left(\eta^{\mathrm{a}}+\eta^{\mathrm{b}}\right)$ is the average of the income elasticity of food in the two countries. To allow for uncertainty in the budget shares and the elasticities of equation $\left(5^{\prime \prime}\right)$, we embed it in the Monte Carlo simulation described above and define the base country as the geometric mean of the 42 countries which now plays the role of country $\mathrm{b}$. Thus write the realisation at trial $\mathrm{s}$ as

$$
\log \left(\frac{\mathrm{Q}^{\mathrm{a}}}{\mathrm{Q}^{*}}\right)^{(\mathrm{s})}=\frac{\log \left(\mathrm{w}^{\mathrm{a}(\mathrm{s})} / \mathrm{w}^{*}\right)}{\eta^{\mathrm{a} *(\mathrm{~s})}-1}-\frac{\left(\phi^{(\mathrm{s})} \eta^{\mathrm{a} *(\mathrm{~s})}+1\right)\left[\log \left(\mathrm{p}^{\mathrm{a}} / \mathrm{p}^{*}\right)-\log \left(\mathrm{P}^{\mathrm{a}} / \mathrm{P}^{*}\right)\right]}{\eta^{\mathrm{a} *(\mathrm{~s})}-1},
$$

where an asterisk $(*)$ denotes the geometric mean over the 42 countries and $\eta^{\mathrm{a}(\mathrm{s})}=\frac{1}{2}\left(\eta^{\mathrm{a}(\mathrm{s})}+\eta^{*(\mathrm{~s})}\right)$ is the average of the income elasticity in a and the base country in trial s.

The experiment yields 1,000 values of the right-hand side of equation $\left(5^{\prime \prime \prime}\right)$ for $\mathrm{a}=1, \ldots, 42$ countries, which are summarised in Table 6. Take the case of Luxembourg as an example. According to the 
first entry of column 2, this country's observed income is about 87 percent greater than the average country. On the basis of the mean of the 1,000 trials of the adjusted food shares (column 3), Luxembourg is estimated to be 63 percent richer than average, so that its income is underestimated by about 24 percent. While this error is substantial, for all countries other than Luxembourg, the USA, Malta and Russia the errors are much smaller, mostly in the range \pm 5 percent; the average error is 0.3 percent, while the average absolute error is 4.2 percent. The closeness of the observed and simulated income is confirmed more formally in Figure 4 which shows that in a regression of actual on predicted, actual $_{c}=\kappa+\lambda \cdot \operatorname{predicted}_{c}$, we are unable to reject the unbiassedness hypothesis whereby $\kappa=0, \lambda=1$. Figure 5 provides a plot of the observed and simulated income differences for each pair of countries. While the simulated "income mountain" is a bit more uneven than its observed counterpart, in general, the two shapes match quite well. Interestingly, a distinct local peak occurs for comparisons between Malta and its neighbours; in addition to being mentioned above, this country distinguishes itself as being an outlier in Figure 2. A measure of the underlying uncertainty of simulated income is given by the standard deviation of its 1,000 values. As can be seen from column 4 of Table 6, the standard deviations are of the order of 20 percent. More will be said about the uncertainty of incomes in the next section.

Next, we use equation ( $\left.5^{\prime \prime \prime}\right)$ to decompose simulated income into two components,

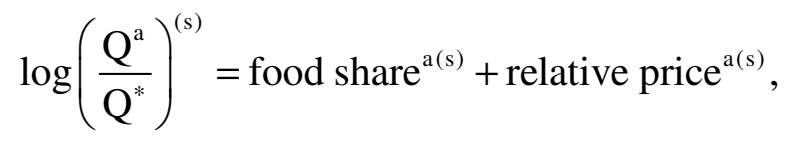

where the components for country a in trial $\mathrm{s}$ are

$$
\text { food share }^{\mathrm{a}(\mathrm{s})}=\frac{\log \left(\mathrm{w}^{\mathrm{a}(\mathrm{s})} / \mathrm{w}^{*}\right)}{\eta^{\mathrm{a}(\mathrm{s})}-1}, \quad \text { relative price }{ }^{\mathrm{a}(\mathrm{s})}=-\frac{\left(\phi^{(\mathrm{s})} \eta^{\mathrm{a}(\mathrm{s})}+1\right)\left[\log \left(\mathrm{p}^{\mathrm{a}} / \mathrm{p}^{*}\right)-\log \left(\mathrm{P}^{\mathrm{a}} / \mathrm{P}^{*}\right)\right]}{\eta^{\mathrm{a}^{*(\mathrm{~s})}}-1} .
$$

Column 7 of Table 6 reveals that with a couple of exceptions, the relative price component increases as income falls, reflecting that on average food is relatively more expensive in poorer countries. In most cases, this component is substantial, accounting for about 30 percent of the income differences on average, so that ignoring it would lead to serious distortion. The dependence of simulated income on the relative price of food is given by the term $-\left(\phi^{(\mathrm{s})} \eta^{\mathrm{a} *(\mathrm{~s})}+1\right) /\left(\eta^{\mathrm{a} *(\mathrm{~s})}-1\right)$; as $-\left(\eta^{\mathrm{a} *(\mathrm{~s})}-1\right)>0$, the sign of this term hinges on that of the numerator $\left(\phi^{(s)} \eta^{\mathrm{a} *(\mathrm{~s})}+1\right)$. It is reasonable to expect the income flexibility to be a negative fraction and the food income elasticity to be a positive fraction, so it is likely that $\left(\phi^{(\mathrm{s})} \eta^{\mathrm{a} *(\mathrm{~s})}+1\right)>0$. In this case, the direct impact of an increase in the relative food price in increasing its budget share dominates the substitution effect (which decreases the share), so the net effect is for the food share to increase with its price. Consequently, ignoring the rise in food prices for poorer countries fails to exclude this part of the 
higher share, so that in effect we over estimate the food share and under estimate income in those countries. The opposite is true for rich countries, where food is cheaper. Figure 6 plots the income differences against countries and reveals that the curve with no adjustment for prices is mostly steeper than that for when prices are held constant, so that the neglect of prices overstates the dispersion of income. Additionally, the adjustment for prices smoothes out most of the sharp spikes in the income differences.

\section{Stochastic Income Comparisons}

The income comparisons provided by equation $\left(5^{\prime \prime \prime}\right)$ involve two elements of uncertainty, viz., (i) the budget shares are random due to the error term in the demand model, and (ii) the estimation procedure leads to elasticity values that are also random. In this section, we show how the incorporation of this randomness enriches the analysis of cross-country income comparisons.

We start with a summary picture by combining on the basis of income the 42 countries into 6 groups each comprising 7 members, as indicated by the grid lines of Table 1 . Denote these groups by $\mathrm{G}=1, \ldots, 6$ and order them in terms of increasing average income. If $\mathbf{S}_{\mathrm{G}}$ denotes the set of countries in group $\mathrm{G}$, then in trial $\mathrm{s}$ the average income in this group is $\log \left(\mathrm{Q}^{\mathrm{G}} / \mathrm{Q}^{*}\right)^{(\mathrm{s})}=(1 / 7) \sum_{\mathrm{c} \in \mathbf{S}_{\mathrm{G}}} \log \left(\mathrm{Q}^{\mathrm{c}} / \mathrm{Q}^{*}\right)^{(\mathrm{s})}$. Group G's income relative

to group $\mathrm{H}^{\prime}$ 's is then $\log \left(\mathrm{Q}^{\mathrm{G}} / \mathrm{Q}^{\mathrm{H}}\right)^{(\mathrm{s})}=\log \left(\mathrm{Q}^{\mathrm{G}} / \mathrm{Q}^{*}\right)^{(\mathrm{s})}-\log \left(\mathrm{Q}^{\mathrm{H}} / \mathrm{Q}^{*}\right)^{(\mathrm{s})}$, and Figure 7 contains for all pairs of groups, histograms of relative incomes for the $s=1, \ldots, 1,000$ trials. Consider the first row, which refers to the richest group of countries. As we move from left to right along this row, we compare income in this group to those of other groups that become successively less poor; in other words, this move involves comparing groups that become closer together on the income scale. Thus, as expected, the centres of gravity of the histograms move in the direction of zero along the journey from left to right. The same pattern applies to the other four rows of the figure, as well as to the five columns, for the same reason. Note also that visually the dispersion of the 15 histograms seems to be more or less the same.

The above impression of similar dispersion is confirmed by the standard deviations given in Table 7 , which lies in the modest range of 8-10 percent. This table also contains the mean of each income-difference distribution and for all pairs, the probability that income in a richer group is greater than that in a poorer country. These probabilities reflect the uncertainty of this approach to income comparisons, and convey useful information about the precision of the ranking of countries. The last element in each "probability column" of the table refers to adjacent countries on the income scale, and tells us the probability that the ostensibly richer country is more affluent than its poorer neighbour. These probabilities are as follows: 


\begin{tabular}{ccc}
\hline Income & $\begin{array}{c}\text { Comparison of } \\
\text { country } \\
\text { groups } \mathrm{G}, \mathrm{H}\end{array}$ & $\begin{array}{c}\text { Probability that } \mathrm{G} \text { is richer } \\
\text { than } \mathrm{H} \\
\mathrm{P}\left(\mathrm{Q}^{\mathrm{G}}>\mathrm{Q}^{\mathrm{H}}\right)\end{array}$ \\
\hline Richer & 1,2 & 0.834 \\
& 2,3 & 0.867 \\
& 3,4 & 0.979 \\
& 4,5 & 0.998 \\
Poorer & 5,6 & 1.000 \\
\hline
\end{tabular}

As the probability that group 1 is richer than group 2 is 83 percent, while that between the bottom two is 100 percent, we can say that the first two groups are less distinct on the income scale than the last two. In fact, as the probabilities in the last column above always increase as we move from the top to the bottom, there is a systematic tendency for the contrast between the poorer groups to be more distinct than that between the richer. But as the probabilities are all reasonably high, at the country-group level of aggregation, it is fair to say that there is not a great deal of stochastic overlap between groups.

Next, we descend from high-level income comparisons involving groups and consider more detail by applying the same approach to individual countries. We compare the distribution of income in richer country a with that in a poorer country $\mathrm{b}$ by means of the probability $\mathrm{P}\left(\mathrm{Q}^{\mathrm{a}}>\mathrm{Q}^{\mathrm{b}}\right)$. When this probability is near one, there is little overlap in the income distributions of the two countries, so they are more distinct on the income scale. Figure 8 plots these probabilities for all pairs of countries. The one-step-removed diagonal elements of this figure refer to comparisons of adjacent countries, and the probability of income differences among these pairs is of the order of one-half. Thus, in contrast to the result for groups, this shows that these countries are not really distinct at all. In other words, as the precise ranking of individual countries is not too reliable, for purposes of income comparisons it makes more sense to locate countries in broad groups.

As countries become more distant from each other, the probability of income differences rises. In Figure 8, as we move away from the diagonal (which compares neighbouring countries), and travel in a northerly or westerly direction, or any linear combination thereof, we encounter pairs of countries more distant on the income scale. There is a distinct tendency for the probability surface in the figure to increase with such a move, which reflects that incomes are more likely to differ the greater the distance between countries, or the more "exotic" or "foreign" they are. This idea is perused in Table 8 which tabulates the probability of income differences by the distance separating countries, with distance interpreted as the difference in the income ranking. As can be seen, according to both the marginal and cumulative probability concepts, as the distance between countries increases so does the probability that they have different incomes. Surprisingly, the probability of income differences jumps the most in moving to immediately 
adjacent countries; e. g., from column 2 of Table $8, P\left(\mathrm{Q}^{\mathrm{c}}>\mathrm{Q}^{\mathrm{c}+\mathrm{x}}\right)$ jumps from 0 to 0.6 as the band width increases from $x=0$ (same countries) to $x=1$ (neighbouring countries).

\section{Concluding Comments}

This paper has reconsidered the old, but fundamental problem of measuring the wealth of nations. We argued that the share of total consumption expenditure devoted to food (the food budget share) has several attractive features as an inverse measure of affluence. As it is a pure number that is independent of the price level and currency units, it is readily compared across time and countries. Additionally, fairly reliable information on the food budget share is available in most countries. Finally, the relation between this share and income is one of the most studied in economics and is enshrined in Engel's law. We demonstrated that once differences in food prices are allowed for, the food budget share provides a method of estimating incomes across countries that is a viable alternative to that provided by the PPP measures of the International Comparisons Project of the World Bank. Our approach offers estimates of international incomes that are more timely than the alternatives and can even serve as an independent check on them.

Our rule for measuring international income differences is given by equation $\left(5^{\prime \prime}\right)$. This implies that the estimate of per capita income of country a, $Q^{a}$, in terms of country $b, Q^{a}$, can be formulated as

$$
\log \left(\frac{\mathrm{Q}^{\mathrm{a}}}{\mathrm{Q}^{\mathrm{b}}}\right)=\frac{1}{\eta^{\mathrm{ab}}-1}\left\{\log \left(\frac{\mathrm{w}^{\mathrm{a}}}{\mathrm{w}^{\mathrm{b}}}\right)-\Delta \log \left(\frac{\mathrm{w}^{\mathrm{a}}}{\mathrm{w}^{\mathrm{b}}}\right)\right\},
$$

where $\eta^{\mathrm{ab}}$ is the average food income elasticity, $\mathrm{w}^{\mathrm{a}}$ and $\mathrm{w}^{\mathrm{b}}$ are the food budget shares in the two countries, $\Delta \log \left(\mathrm{w}^{\mathrm{a}} / \mathrm{w}^{\mathrm{b}}\right)=\left(\phi \eta^{\mathrm{ab}}+1\right)\left[\log \left(\mathrm{p}^{\mathrm{a}} / \mathrm{P}^{\mathrm{a}}\right)-\log \left(\mathrm{p}^{\mathrm{b}} / \mathrm{P}^{\mathrm{b}}\right)\right]$ is the change in the log ratio of the shares on account of the different relative food prices, and $\phi$ is the income flexibility (the reciprocal of the income elasticity of the marginal utility of the income). Thus as our measure of income differences just depends on two basic elements:

- The food budget shares and prices in the two countries, which are readily observable.

- Two parameters, the food income elasticity and the income flexibility, for which many estimates are available.

The workings of this rule can be illustrated with two very different countries, $a=$ Romania (to be denoted by $R$ ) and $b=$ France $(F)$. The observed food budget shares are $\mathrm{w}^{\mathrm{R}}=0.310, \mathrm{w}^{\mathrm{F}}=0.114$, so that their ratio is $\mathrm{w}^{\mathrm{R}} / \mathrm{w}^{\mathrm{F}}=2.72$, as indicated by the first entry in column 2 of Table 9 . The results of Table 5 imply that the average food income elasticity is 0.4 , while the income flexibility is -0.8 . When these parameters are used to adjust for the higher food prices in Romania, the ratio of shares falls from 2.72 to 2.35 , as shown in the first entry of column 3 of Table 9. The last row of the table reveals that Romania is estimated to be 81 
percent poorer than France if the price differences are ignore, while it is 76 percent poorer once we adjust for prices. On a PPP basis, the observed volumes of total consumption per capita in the two countries are $\mathrm{Q}^{\mathrm{R}}=\$ 5,336, \mathrm{Q}^{\mathrm{F}}=\$ 18,439$, so that Romania is "in fact" 71 percent poorer. Accordingly, our estimate of Romania being 76 percent poorer is to be compared with the more comprehensive PPP measure of 71 percent. Although the agreement is not perfect, the discrepancy is modest and points to the practical usefulness of our short-cut approach when data are lacking. 


\section{APPENDIX}

All data are from the OECD (2004) and refer to 42 countries that were members of the OECD in 2002. To describe the data, let $p_{i c}$ be the price of consumer good $i(i=1, \ldots, 12)$ in country $c(c=1, \ldots, 42)$, expressed in terms of the currency of that country, and $\mathrm{q}_{\mathrm{ic}}$ be the corresponding per capita quantity consumed. Thus, $p_{i c} q_{i c}$ is the expenditure on $i$ and if we write $M_{c}=\sum_{i=1}^{12} p_{i c} q_{i c}$ for total consumption expenditure, $w_{i c}=p_{i c} q_{i c} / M_{c}$ is then the share of the total devoted to $i$, with $\sum_{i=1}^{12} w_{i c}=1$. These $w_{i c}$ are known as "budget shares". Lines 2-13 of Table 1.1 of OECD (2004) contain $\mathrm{p}_{\mathrm{ic}} \mathrm{q}_{\mathrm{ic}} \times($ population of $\mathrm{c})$, from which the budget shares can be derived. These are given in Table A1. Here countries are ranked in terms of decreasing per capita affluence as measured by the volume of total consumption, which is described below. The second entry in column 2 of Table A1, for example, tells us that Americans devote 6.4 percent of their total consumption expenditure to food. Details of the 12 commodities are as follows:

\begin{tabular}{ll}
\hline Description & Abbreviation \\
\hline Food and non-alcoholic beverages & Food \\
Alcoholic beverages, tobacco and narcotics & Alcohol \& tobacco \\
Clothing and footwear & Clothing \\
Housing, water, electricity, gas and other fuels & Housing \\
Household furnishings, equip. and maintenance & Durables \\
Health & Health \\
Transport & Transport \\
Communication & Comm \\
Recreation and culture & Recreation \\
Education & Education \\
Restaurants and hotels & Restaurants \\
Miscellaneous goods and services & Other \\
\hline
\end{tabular}

Let $\mathrm{p}_{\mathrm{i}}^{*}$ be the "world" price of good $\mathrm{i}$, defined as the OECD average, expressed in terms of US dollars. As one US dollar buys $1 / \mathrm{p}_{\mathrm{i}}^{*}$ units of commodity $\mathrm{i}$ at the world price, the ratio $\mathrm{p}_{\mathrm{ic}} / \mathrm{p}_{\mathrm{i}}^{*}$ is interpreted as the domestic-currency cost of a US dollar's worth of this good. Accordingly, we shall refer to $\mathrm{p}_{\mathrm{ic}} / \mathrm{p}_{\mathrm{i}}^{*}$ as the "purchasing-power-parity (PPP) price" of good i. Table A2, from lines 2-13 of Table 1.2 of OECD (2004), give the price ratios $\mathrm{p}_{\mathrm{ic}} / \mathrm{p}_{\mathrm{i}}^{*}$. To illustrate, consider the second entry in column 2 of Table A2, 0.95. This means that the volume of food that can be purchased with one US dollar at average OECD prices costs \$US0.95 in the US, implying that food is 5 percent cheaper in the US than in the OECD in general. 
If we use the PPP price to deflate domestic expenditure $\mathrm{p}_{\mathrm{ic}} \mathrm{q}_{\mathrm{ic}}$, we obtain

$$
\frac{p_{i c} q_{i c}}{p_{i c} / p_{i}^{*}}=p_{i}^{*} q_{i c}
$$

which is the per capita volume of consumption of $\mathrm{i}$, evaluated at the world price. As a uniform set of prices is used in all countries, the OECD refer to (A1) as "real expenditure". As each of the $\mathrm{i}=1, \ldots, 12$ commodities is measured in terms of US dollars, they can be added over commodities to yield

$$
\mathrm{Q}_{\mathrm{c}}=\sum_{\mathrm{i}=1}^{12} \mathrm{p}_{\mathrm{i}}^{*} \mathrm{q}_{\mathrm{ic}},
$$

which is a measure of the volume of total consumption per capita. This $Q_{c}$ is a measure of affluence per capita, and is used to rank countries. Lines 2-13 of Table 1.7 of OECD (2004) give $p_{i}^{*} q_{i c} \times($ population of c), so that deflating by population (line 39 of Table 1.1) we derive the per capita volume of consumption $p_{\mathrm{i}}^{*} q_{\mathrm{ic}}$. These data are given in columns 2-13 of Table A3, while column 14 gives the total volume of consumption $\mathrm{Q}_{\mathrm{c}}$, as defined by equation (A2).

Next, consider a budget-share weighted geometric average of the PPP prices in country c. In logarithmic form, this is

$$
\log \mathrm{P}_{\mathrm{c}}=\sum_{\mathrm{i}=1}^{12} \mathrm{~W}_{\mathrm{ic}} \log \left(\frac{\mathrm{p}_{\mathrm{ic}}}{\mathrm{p}_{\mathrm{i}}^{*}}\right)=\log \mathrm{P}_{\mathrm{c}}^{\prime}-\log \mathrm{P}_{\mathrm{c}}^{*},
$$

where $\log \mathrm{P}_{\mathrm{c}}^{\prime}=\sum_{\mathrm{i}=1}^{12} \mathrm{w}_{\mathrm{ic}} \log \mathrm{p}_{\mathrm{ic}}$ is the conventional cost-of-living index for country $\mathrm{c}$ and $\log \mathrm{P}_{\mathrm{c}}^{*}=\sum_{\mathrm{i}=1}^{12} \mathrm{~W}_{\mathrm{ic}} \log \mathrm{p}_{\mathrm{i}}^{*}$ is a budget-share weighted average of the world prices. The $\mathrm{c}$ subscript on $\log \mathrm{P}_{\mathrm{c}}^{*}$ reflects the use of country c's budget shares as weights in this index. The index $\log \mathrm{P}_{\mathrm{c}}$ is a measure of the price level, in terms of PPP, in country c. A measure of the price level in country a relative to that in b is

$$
\log \frac{\mathrm{P}_{\mathrm{a}}}{\mathrm{P}_{\mathrm{b}}}=\log \mathrm{P}_{\mathrm{a}}^{\prime}-\log \mathrm{P}_{\mathrm{b}}^{\prime}-\sum_{\mathrm{i}=1}^{12}\left(\mathrm{w}_{\mathrm{ia}}-\mathrm{w}_{\mathrm{ib}}\right) \log \mathrm{p}_{\mathrm{i}}^{*}
$$

If the budget shares in the two countries are not too different, as would be the case if they were about equally affluent, and more or less shared the same structure of relative prices, then the last term on the righthand side of the above equation is near zero and

$$
\log \frac{\mathrm{P}_{\mathrm{a}}}{\mathrm{P}_{\mathrm{b}}} \approx \log \frac{\mathrm{P}_{\mathrm{a}}^{\prime}}{\mathrm{P}_{\mathrm{b}}^{\prime}} .
$$

In words, if the budget shares are similar in the two countries under consideration, then we can compare relative price levels with either conventional cost-of-living indexes or the PPP versions.

A measure of the PPP price of good i relative to the corresponding price level is 


$$
\log \left(\frac{\mathrm{p}_{\mathrm{ic}} / \mathrm{p}_{\mathrm{i}}^{*}}{\mathrm{P}_{\mathrm{c}}}\right)=\log \frac{\mathrm{p}_{\mathrm{ic}}}{\mathrm{p}_{\mathrm{i}}^{*}}-\log \mathrm{P}_{\mathrm{c}}
$$

This relative price compares the cost in country $c$ of a US dollar's worth of good i with the cost of a market basket, priced at PPP, in the same country. A budget-share weighted average of these relative prices is

$$
\sum_{i=1}^{12} \mathrm{w}_{\mathrm{ic}} \log \left(\frac{\mathrm{p}_{\mathrm{ic}} / \mathrm{p}_{\mathrm{i}}^{*}}{\mathrm{P}_{\mathrm{c}}}\right)=0
$$

so that not all relative prices can move in the same direction, as required. We use equation (A4) and the information contained in Tables A1 and A2 to define the relative prices of the 12 goods in the 42 countries, and the results, in logarithmic form, are contained in Table A4.

It is clear that the (logarithmic) PPP price of good $i$ in terms of good $j$ is just the difference between the left-hand side of (A4) for $\mathrm{i}$ and that for $\mathrm{j}$ :

$$
\log \frac{\mathrm{p}_{\mathrm{ic}} / \mathrm{p}_{\mathrm{i}}^{*}}{\mathrm{p}_{\mathrm{jc}} / \mathrm{p}_{\mathrm{j}}^{*}}=\log \left(\frac{\mathrm{p}_{\mathrm{ic}} / \mathrm{p}_{\mathrm{i}}^{*}}{\mathrm{P}_{\mathrm{c}}}\right)-\log \left(\frac{\mathrm{p}_{\mathrm{jc}} / \mathrm{p}_{\mathrm{j}}^{*}}{\mathrm{P}_{\mathrm{c}}}\right) \text {. }
$$

To illustrate the above interpretation, consider the prices of $i=$ food and $j=$ health in the USA. From row 2 of columns 2 and 7 of Tables A2 and A4, we have:

\begin{tabular}{lccc}
\hline Price & $\begin{array}{c}\text { Source } \\
\text { table }\end{array}$ & Food & Health \\
\hline 1. PPP in dollars & A2 & 0.95 & 1.59 \\
2. Logarithmic relative PPP $\times 100$ & A4 & -19.7 & 31.9 \\
\hline
\end{tabular}

From row 1 of the above, the logarithmic PPP price of food in terms of health is

$$
\log \frac{\mathrm{p}_{\mathrm{ic}} / \mathrm{p}_{\mathrm{i}}^{*}}{\mathrm{p}_{\mathrm{jc}} / \mathrm{p}_{\mathrm{j}}^{*}}=\log \left(\frac{0.95}{1.59}\right)=-51.5 \times 10^{-2}
$$

so that food is approximately 52 percent cheaper than health in the USA. This is exactly the same (apart from rounding) as what we get from row 2 of the above for the difference between the two logarithmic relative PPP prices,

$$
\log \left(\frac{\mathrm{p}_{\mathrm{ic}} / \mathrm{p}_{\mathrm{i}}^{*}}{\mathrm{P}_{\mathrm{c}}}\right)-\log \left(\frac{\mathrm{p}_{\mathrm{jc}} / \mathrm{p}_{\mathrm{j}}^{*}}{\mathrm{P}_{\mathrm{c}}}\right)=-19.7-31.9=-51.6\left(\operatorname{all} \times 10^{-2}\right) .
$$

Although goods like food and health involve very different units of measurement (kilograms of food versus the number of visits to the doctor, for example), the above formulation allows meaningful comparisons of their prices to be made. 
To further interpret the relative price measure (A4), consider a logarithmic comparison of the relative price of $\mathrm{i}$ in countries $\mathrm{a}$ and $\mathrm{b}$ :

$$
\log \left(\frac{\frac{\mathrm{p}_{\mathrm{ia}} / \mathrm{p}_{\mathrm{i}}^{*}}{\mathrm{P}_{\mathrm{a}}}}{\frac{\mathrm{p}_{\mathrm{ib}} / \mathrm{p}_{\mathrm{i}}^{*}}{\mathrm{P}_{\mathrm{b}}}}\right)=\log \left(\frac{\mathrm{p}_{\mathrm{ia}} / \mathrm{P}_{\mathrm{a}}}{\mathrm{p}_{\mathrm{ib}} / \mathrm{P}_{\mathrm{b}}}\right)=\log \frac{\mathrm{p}_{\mathrm{ia}}}{\mathrm{p}_{\mathrm{ib}}}-\log \frac{\mathrm{P}_{\mathrm{a}}}{\mathrm{P}_{\mathrm{b}}} .
$$

Using approximation (A3), the above can be expressed as

$$
\log \left(\frac{\frac{\mathrm{p}_{\mathrm{ia}} / \mathrm{p}_{\mathrm{i}}^{*}}{\mathrm{P}_{\mathrm{a}}}}{\frac{\mathrm{p}_{\mathrm{ib}} / \mathrm{p}_{\mathrm{i}}^{*}}{\mathrm{P}_{\mathrm{b}}}}\right) \approx \log \left(\frac{\mathrm{p}_{\mathrm{ia}} / \mathrm{P}_{\mathrm{a}}^{\prime}}{\mathrm{p}_{\mathrm{ib}} / \mathrm{P}_{\mathrm{b}}^{\prime}}\right) .
$$

This equation assures us that cross-country comparisons of relative PPP prices are the same as comparing conventional relative prices, at least as an approximation.

In view of the above material on the measurement of prices, it is worthwhile to comment further on the underlying issue. Due to the homogeneity of demand functions, it is only relative prices that matter for observed consumption behaviour. Results (A3), (A5) and (A6) tell us that as the use of PPP prices do not change relative prices, it is legitimate to use these prices in demand analysis. Another perspective on PPP prices is to think in terms of units of measurement considerations. We observe as a fact expenditure on good $\mathrm{i}$ in country $\mathrm{c}$ expressed in terms of domestic currency units, $\mathrm{p}_{\mathrm{ic}} \mathrm{q}_{\mathrm{ic}}$. We are then free to decompose this expenditure into price and volume components in any way we choose, as long as two conditions are satisfied. (i) The product of the two components must equal the given value of expenditure. (ii) The same decomposition must be employed in all countries. Thus, for example, we could equally use grams of food consumed and the price of a gram, or express both the quantity and price of food in terms of pounds. In other words, prices and quantities are subject to one multiplicative degree of freedom. As $\left\{\mathrm{p}_{\mathrm{ic}} / \mathrm{p}_{\mathrm{i}}^{*}, \mathrm{p}_{\mathrm{i}}^{*} \mathrm{q}_{\mathrm{ic}}\right\}$, and $\left\{\mathrm{p}_{\mathrm{ic}}, \mathrm{q}_{\mathrm{ic}}\right\}$ both satisfy the condition that $($ price $) \times($ quantity $)=($ given expenditure $)$, they are equally acceptable ways of measuring prices and quantities.

Finally, Table A5 gives two versions of GDP per capita, as well as reproducing from Table A3 the volume of total consumption per capita. The PPP version of GDP, given in column 3 of the table, is from line 21 of Table 1.7 (total GDP) and line 39 of Table 1.1 (population) of OECD (2004). The market exchange rate version, given in column 5 of Table A5, is derived from three lines of Table 1.1 of the same publication: Lines 21 (total GDP in domestic currency), 39 (population) and 40 (exchange rate). Columns 4 
and 6 of Table A5 give the two version of GDP in index form; a comparison of these columns shows that market exchange rates lead to an amplification of cross-country inequality in GDP, as is well known. 


\section{REFERENCES}

Barlow, R. (1977). “A Test of Alternative Methods of Making GNP Comparisons.” Economic Journal 87: 450-59.

Bennett, M. K. (1951). "International Disparities in Consumption Levels." American Economic Review 41: 632-49.

Beckerman, W., and R. Bacon (1966). "International Comparisons of Income Levels: A Suggested New Measure." Economic Journal 76: 519-36.

Chua, G. (2003). "Food and Cross-Country Income Comparisons.” Economics Discussion Paper No 03.14, Business School, The University of Western Australia.

Costa, D. L. (2001). "Estimating Real Income in the United States from 1888 to 1994: Correcting CPI Bias Using Engel Curves." Journal of Political Economy 109: 1288-1310.

Duggar, J. W. (1969). "International Comparisons of Income Levels: An Additional Measure." Economic Journal 79: 109-16.

Engel, E. (1857). "Die Productions- und Consumptionsverhaltnisse des Konigreichs Sachsen.” Reprinted in Engel's Die Lebenskosten belgischer Atbeiter-Familien. Dresden, 1895.

Ehrlich, E. (1969). "Dynamic International Comparison of National Incomes Expressed in Terms of Physical Indicators." Osteuropa Wirtschaft 14, 1.

Hamilton B. W. (2001). “Using Engel's Law to Estimate CPI Bias.” American Economic Review 91: 619-30.

Heston, A. (1973). "A Comparison of Some Short-Cut Methods of Estimating Real Product Per Capita." Review of Income and Wealth 19: 79-104.

Janossy, F. (1963). A Gazdasagi Fejlettseg Merhetosege es uj Meresi Modszere. (The Measurability and a New Measuring Method of Economic Development Level.) Budapest: Kozgazdasagi es Jogi Konyvkiado.

Leser, C. E. V. (1963). "Forms of Engel Functions.” Econometrica 31: 694-703.

OECD (2004). Purchasing Power Parities and Real Expenditures: 2002 Benchmark Year. Paris: Eurostat and OECD.

Nakamura, L. (1996). “Is US Economic Performance Really that Bad?” Working Paper No 95, Federal Reserve Bank of Philadelphia.

Orshansky, M. (1965). "Counting the Poor: Another Look at the Poverty Profile.” Social Security Bulletin 28: 3-29.

Orshansky, M. (1969). "How Poverty is Measured." Monthly Labor Review 92: 37-41.

Rao, V. V. B. (1981). "Measurement of Deprivation and Poverty Based on the Proportion Spent on Food: An Exploratory Exercise." World Development 9: 337-53.

Sahn, D. A., and D. Stifel (2003). "Exploring Alternative Measures of Welfare in the Absence of Expenditure Data." Review of Income and Wealth 49: 463-89.

Steckel, R. H. (1995). "Stature and the Standard of Living." Journal of Economic Literature 33: 1903-40.

Stigler, G. J. (1954). "The Early History of Empirical Studies in Consumer Behaviour.” Journal of Political Economy 62: 95-113.

Theil, H. (1975/76). Theory and Measurement of Consumer Demand. Two volumes. Amsterdam: North-Holland.

Theil, H. (1980). The System-Wide Approach to Microeconomics. Chicago: The University of Chicago Press.

Theil, H., C.-F. Chung and J. L. Seale Jr (1989). International Evidence on Consumption Patterns. Greenwich, Conn.: JAI Press.

Theil, H., and K. W. Clements (1987). Applied Demand Analysis: Results from System-Wide Approaches. Cambridge Mass.: Ballinger Publishing Co.

Van Praag, B. M. S., J. S. Spit and H. Van de Stadt (1982). "A Comparison between the Food Ratio Poverty Line and the Leyden Poverty Line." Review of Economics and Statistics 64: 691-94.

Working, H. (1943). "Statistical Laws of Family Expenditure." Journal of the American Statistical Association 38: 43-56. 
TABLE 1

AFFLUENCE AND FOOD, 42 COUNTRIES IN 2002

\begin{tabular}{|c|c|c|}
\hline Country & $\begin{array}{l}\text { Consumption per capita } \\
\text { (US dollars) } \\
\text { (2) }\end{array}$ & $\begin{array}{l}\text { Food budget share } \\
\qquad \times 100) \\
(3)\end{array}$ \\
\hline 1. L'bourg & 30,258 & 7.7 \\
\hline 2. USA & 24,768 & 6.4 \\
\hline 3. UK & 20,899 & 7.6 \\
\hline 4. S'land & 19,424 & 9.6 \\
\hline 5. Austria & 19,161 & 8.8 \\
\hline 6. Norway & 18,691 & 10.6 \\
\hline 7. France & 18,439 & 11.4 \\
\hline 8. Iceland & 18,358 & 13.9 \\
\hline 9. Denmark & 18,145 & 8.8 \\
\hline 10. Sweden & 17,934 & 8.7 \\
\hline 11. N'lands & 17,871 & 8.7 \\
\hline 12. Canada & 17,736 & 8.0 \\
\hline 13. Belgium & 17,735 & 10.4 \\
\hline 14. Australia & 17,443 & 9.2 \\
\hline 15. Italy & 17,403 & 12.2 \\
\hline 16. Germany & 16,941 & 9.8 \\
\hline 17. Cyprus & 15,969 & 13.6 \\
\hline 18. Ireland & 15,965 & 6.3 \\
\hline 19. Japan & 15,788 & 12.3 \\
\hline 20. Spain & 15,701 & 13.5 \\
\hline 21. Finland & 15,596 & 9.6 \\
\hline 22. NZ & 14,390 & 11.4 \\
\hline 23. Israel & 14,358 & 14.6 \\
\hline 24. Greece & 13,691 & 14.5 \\
\hline 25. Malta & 13,669 & 16.0 \\
\hline 26. Portugal & 13,156 & 15.1 \\
\hline 27. Slovenia & 11,993 & 13.9 \\
\hline 28. Czech & 11,229 & 14.1 \\
\hline 29. Hungary & 10,381 & 15.1 \\
\hline 30. Korea & 9,717 & 13.4 \\
\hline 31. Slovakia & 9,218 & 19.2 \\
\hline 32. Croatia & 8,918 & 22.3 \\
\hline 33. Poland & 8,729 & 17.7 \\
\hline 34. Lithuania & 8,581 & 23.8 \\
\hline 35. Estonia & 8,374 & 18.4 \\
\hline 36. Latvia & 7,330 & 21.3 \\
\hline 37. Mexico & 6,756 & 21.7 \\
\hline 38. Bulgaria & 5,567 & 22.9 \\
\hline 39. Russia & 5,499 & 27.3 \\
\hline 40. Romania & 5,336 & 31.0 \\
\hline 41. Macedonia & 5,123 & 29.8 \\
\hline 42. Turkey & 4,882 & 24.6 \\
\hline
\end{tabular}


TABLE 2

MATRIX OF CHANGES IN FOOD BUDGET SHARES FOR 42 COUNTRIES

$\Delta \mathrm{w}^{\mathrm{ab}} \times 100$

\begin{tabular}{|c|c|c|c|c|c|c|c|c|c|c|c|c|c|c|c|c|c|c|c|c|c|c|c|c|c|c|c|c|c|c|c|c|c|c|c|c|c|c|c|c|c|}
\hline & 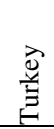 & 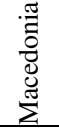 & 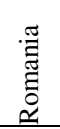 & 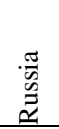 & 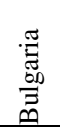 & 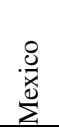 & 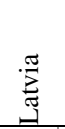 & 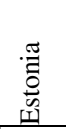 & 㞼 & $\begin{array}{l}\overrightarrow{7} \\
\text { 吾 } \\
0\end{array}$ & 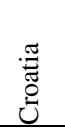 & 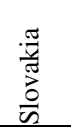 & 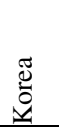 & $\begin{array}{l}\text { 局 } \\
\text { of } \\
\text { 至 } \\
\end{array}$ & 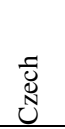 & $\begin{array}{l}\text { 乑 } \\
\frac{\partial}{n}\end{array}$ & 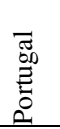 & $\frac{\sqrt[\pi]{\pi}}{\sum}$ & 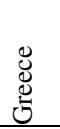 & $\begin{array}{l}\overline{\mathbb{w}} \\
\stackrel{⿹}{g}\end{array}$ & $\mathrm{Z}$ & 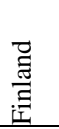 & $\begin{array}{l}\text { 寻 } \\
\text { की }\end{array}$ & 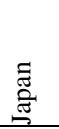 & 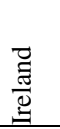 & 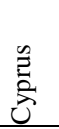 & 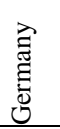 & 吾 & 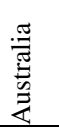 & 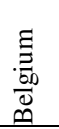 & 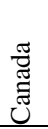 & $\begin{array}{l}\tilde{\Xi} \\
\frac{\vec{\Xi}}{\bar{z}}\end{array}$ & 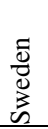 & 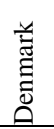 & $\begin{array}{l}\text { 芯 } \\
\text { 总 } \\
\end{array}$ & 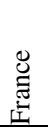 & 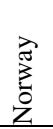 & 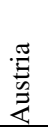 & $\begin{array}{l}\overrightarrow{\tilde{E}} \\
\overline{\bar{n}}\end{array}$ & 光 & $\begin{array}{l}\mathbb{2} \\
\stackrel{2}{2}\end{array}$ \\
\hline L'bourg & -17 & -22 & -23 & -20 & -15 & -14 & -14 & -11 & -16 & -10 & -15 & -12 & -6 & $\begin{array}{l}-7 \\
\end{array}$ & -6 & -6 & -7 & -8 & -7 & -7 & -4 & -2 & -6 & -5 & 1 & -6 & -2 & -5 & -2 & -3 & 0 & -1 & -1 & -1 & -6 & -4 & -3 & -1 & -2 & 0 & 1 \\
\hline USA & -18 & -23 & -25 & -21 & -16 & -15 & -15 & -12 & -17 & -11 & -16 & -13 & -7 & -9 & -8 & -7 & -9 & -10 & -8 & -8 & -5 & -3 & -7 & -6 & 0 & -7 & -3 & -6 & -3 & -4 & -2 & -2 & -2 & -2 & -7 & -5 & -4 & -2 & -3 & -1 & \\
\hline UK & -17 & -22 & -23 & -20 & -15 & -14 & -14 & -11 & -16 & -10 & -15 & -12 & -6 & -8 & -7 & -6 & -8 & -8 & -7 & -7 & -4 & -2 & -6 & -5 & 1 & -6 & -2 & -5 & -2 & -3 & 0 & -1 & -1 & -1 & -6 & -4 & -3 & -1 & -2 & & \\
\hline S'land & -15 & -20 & -21 & -18 & -13 & -12 & -12 & -9 & -14 & -8 & -13 & -10 & -4 & -6 & -4 & -4 & -6 & -6 & -5 & -5 & -2 & 0 & -4 & -3 & 3 & -4 & 0 & -3 & 0 & -1 & 2 & 1 & 1 & 1 & -4 & -2 & -1 & 1 & & & \\
\hline Austria & -16 & -21 & -22 & -19 & -14 & -13 & -12 & -10 & -15 & -9 & -13 & -10 & -5 & -6 & -5 & -5 & -6 & -7 & -6 & -6 & -3 & -1 & -5 & -3 & 3 & -5 & -1 & -3 & 0 & -2 & 1 & 0 & 0 & 0 & -5 & -3 & -2 & & & & \\
\hline Norway & -14 & -19 & -20 & -17 & -12 & -11 & -11 & -8 & -13 & -7 & -12 & -9 & -3 & -5 & -3 & -3 & -5 & -5 & -4 & -4 & -1 & 1 & -3 & -2 & 4 & -3 & 1 & -2 & 1 & 0 & 3 & 2 & 2 & 2 & -3 & -1 & & & & & \\
\hline France & -13 & -18 & -20 & -16 & -11 & -10 & -10 & -7 & -12 & -6 & -11 & -8 & -2 & -4 & -3 & -2 & -4 & -5 & -3 & -3 & 0 & 2 & -2 & -1 & 5 & -2 & 2 & -1 & 2 & 1 & 3 & 3 & 3 & 3 & -2 & & & & & & \\
\hline Iceland & -11 & -16 & -17 & -13 & -9 & -8 & -7 & -4 & -10 & -4 & -8 & -5 & 0 & -1 & 0 & 0 & -1 & -2 & -1 & -1 & 2 & 4 & 0 & 2 & 8 & 0 & 4 & 2 & 5 & 3 & 6 & 5 & 5 & 5 & & & & & & & \\
\hline Denmark & -16 & -21 & -22 & -19 & -14 & -13 & -12 & -10 & -15 & -9 & -13 & -10 & -5 & -6 & -5 & -5 & -6 & -7 & -6 & -6 & -3 & -1 & -5 & -3 & 3 & -5 & -1 & -3 & 0 & -2 & 1 & 0 & 0 & & & & & & & & \\
\hline Sweden & -16 & -21 & -22 & -19 & -14 & -13 & -13 & -10 & -15 & -9 & -14 & -10 & -5 & -6 & -5 & -5 & -6 & -7 & -6 & -6 & -3 & -1 & -5 & -4 & 2 & -5 & -1 & -4 & -1 & -2 & 1 & 0 & & & & & & & & & \\
\hline N'lands & -16 & -21 & -22 & -19 & -14 & -13 & -13 & -10 & -15 & -9 & -14 & -10 & -5 & -6 & -5 & -5 & -6 & -7 & -6 & -6 & -3 & -1 & -5 & -4 & 2 & -5 & -1 & -4 & -1 & -2 & 1 & & & & & & & & & & \\
\hline Canada & -17 & -22 & -23 & -19 & -15 & -14 & -13 & -10 & -16 & -10 & -14 & -11 & -5 & -7 & -6 & -6 & -7 & -8 & -6 & -7 & -3 & -2 & -6 & -4 & 2 & -6 & -2 & -4 & -1 & -2 & & & & & & & & & & & \\
\hline Belgium & -14 & -19 & -21 & -17 & -12 & -11 & -11 & -8 & -13 & -7 & -12 & -9 & -3 & -5 & -4 & -3 & -5 & -6 & -4 & -4 & -1 & 1 & -3 & -2 & 4 & -3 & 1 & -2 & 1 & & & & & & & & & & & & \\
\hline Australia & -15 & -21 & -22 & -18 & -14 & -13 & -12 & -9 & -15 & -9 & -13 & -10 & -4 & -6 & -5 & -5 & -6 & -7 & -5 & -5 & -2 & 0 & -4 & -3 & 3 & -4 & -1 & -3 & & & & & & & & & & & & & \\
\hline Italy & -12 & -18 & -19 & -15 & -11 & -10 & -9 & -6 & -12 & -6 & -10 & -7 & -1 & -3 & -2 & -2 & -3 & -4 & -2 & -2 & 1 & 3 & -1 & 0 & 6 & -1 & 2 & & & & & & & & & & & & & & \\
\hline Germany & -15 & -20 & -21 & -17 & -13 & -12 & -11 & -9 & -14 & -8 & -12 & -9 & -4 & -5 & -4 & -4 & -5 & -6 & -5 & -5 & -2 & 0 & -4 & -2 & 4 & -4 & & & & & & & & & & & & & & & \\
\hline Cyprus & -11 & -16 & -17 & -14 & -9 & -8 & -8 & -5 & -10 & -4 & -9 & -6 & 0 & -2 & 0 & 0 & -1 & -2 & -1 & -1 & 2 & 4 & 0 & 1 & 7 & & & & & & & & & & & & & & & & \\
\hline Ireland & -18 & -24 & -25 & -21 & -17 & -15 & -15 & -12 & -18 & -11 & -16 & -13 & -7 & -9 & -8 & -8 & -9 & -10 & -8 & -8 & -5 & -3 & -7 & -6 & & & & & & & & & & & & & & & & & \\
\hline Japan & -12 & -18 & -19 & -15 & -11 & -9 & -9 & -6 & -12 & -5 & -10 & -7 & -1 & -3 & -2 & -2 & -3 & -4 & -2 & -2 & 1 & 3 & -1 & & & & & & & & & & & & & & & & & & \\
\hline Spain & -11 & -16 & -17 & -14 & -9 & -8 & -8 & -5 & -10 & -4 & -9 & -6 & 0 & -2 & -1 & 0 & -2 & -3 & -1 & -1 & 2 & 4 & & & & & & & & & & & & & & & & & & & \\
\hline Finland & -15 & -20 & -21 & -18 & -13 & -12 & -12 & -9 & -14 & -8 & -13 & -10 & -4 & -5 & -4 & -4 & -5 & -6 & -5 & -5 & -2 & & & & & & & & & & & & & & & & & & & & \\
\hline $\mathrm{NZ}$ & -13 & -18 & -20 & -16 & -11 & -10 & -10 & -7 & -12 & -6 & -11 & -8 & -2 & -4 & -3 & -2 & -4 & -5 & -3 & -3 & & & & & & & & & & & & & & & & & & & & & \\
\hline Israel & -10 & -15 & -16 & -13 & -8 & -7 & -7 & -4 & -9 & -3 & -8 & -5 & 1 & -1 & 1 & 1 & -1 & -1 & 0 & & & & & & & & & & & & & & & & & & & & & & \\
\hline Greece & -10 & -15 & -16 & -13 & -8 & -7 & -7 & -4 & -9 & -3 & -8 & -5 & 1 & -1 & 0 & 1 & -1 & -2 & & & & & & & & & & & & & & & & & & & & & & & \\
\hline Malta & 1 & 2 & 2 & 1 & 3 & -3 & -6 & -2 & -8 & -2 & -5 & -6 & -7 & -11 & -15 & -14 & -9 & & & & & & & & & & & & & & & & & & & & & & & & \\
\hline Portugal & -9 & -15 & -16 & -12 & -8 & -7 & -6 & -3 & -9 & -3 & -7 & -4 & 2 & 0 & 1 & 1 & & & & & & & & & & & & & & & & & & & & & & & & & \\
\hline Slovenia & -11 & -16 & -17 & -13 & -9 & -8 & -7 & -5 & -10 & -4 & -8 & -5 & 0 & -1 & 0 & & & & & & & & & & & & & & & & & & & & & & & & & & \\
\hline Czech & -11 & -16 & -17 & -13 & -9 & -8 & -7 & -4 & -10 & -4 & -8 & -5 & 1 & -1 & & & & & & & & & & & & & & & & & & & & & & & & & & & \\
\hline Hungary & -9 & -15 & -16 & -12 & -8 & -7 & -6 & -3 & -9 & -3 & -7 & -4 & 2 & & & & & & & & & & & & & & & & & & & & & & & & & & & & \\
\hline Korea & -11 & -16 & -18 & -14 & -9 & -8 & -8 & -5 & -10 & -4 & -9 & -6 & & & & & & & & & & & & & & & & & & & & & & & & & & & & & \\
\hline Slovakia & -5 & -11 & -12 & -8 & -4 & -3 & -2 & 1 & -5 & 1 & -3 & & & & & & & & & & & & & & & & & & & & & & & & & & & & & & \\
\hline Croatia & -2 & -8 & -9 & -5 & -1 & 1 & 1 & 4 & -2 & 5 & & & & & & & & & & & & & & & & & & & & & & & & & & & & & & & \\
\hline Poland & -7 & -12 & -13 & -10 & -5 & -4 & -4 & -1 & -6 & & & & & & & & & & & & & & & & & & & & & & & & & & & & & & & & \\
\hline Lithuania & -1 & -6 & -7 & -4 & 1 & 2 & 3 & 5 & & & & & & & & & & & & & & & & & & & & & & & & & & & & & & & & & \\
\hline Estonia & -6 & -11 & -13 & -9 & -5 & -3 & -3 & & & & & & & & & & & & & & & & & & & & & & & & & & & & & & & & & & \\
\hline Latvia & -3 & -9 & -10 & -6 & -2 & 0 & & & & & & & & & & & & & & & & & & & & & & & & & & & & & & & & & & & \\
\hline Mexico & -3 & -8 & -9 & -6 & -1 & & & & & & & & & & & & & & & & & & & & & & & & & & & & & & & & & & & & \\
\hline Bulgaria & -2 & -7 & -8 & -4 & & & & & & & & & & & & & & & & & & & & & & & & & & & & & & & & & & & & & \\
\hline Russia & 3 & -2 & -4 & & & & & & & & & & & & & & & & & & & & & & & & & & & & & & & & & & & & & & \\
\hline Romania & 6 & 1 & & & & & & & & & & & & & & & & & & & & & & & & & & & & & & & & & & & & & & & \\
\hline Macedonia & 5 & & & & & & & & & & & & & & & & & & & & & & & & & & & & & & & & & & & & & & & & \\
\hline
\end{tabular}


TABLE 3

\section{MATRIX OF CHANGES IN INCOMES FOR 42 COUNTRIES}

\section{$\Delta \log \mathrm{Q}^{\mathrm{ab}} \times 100$}

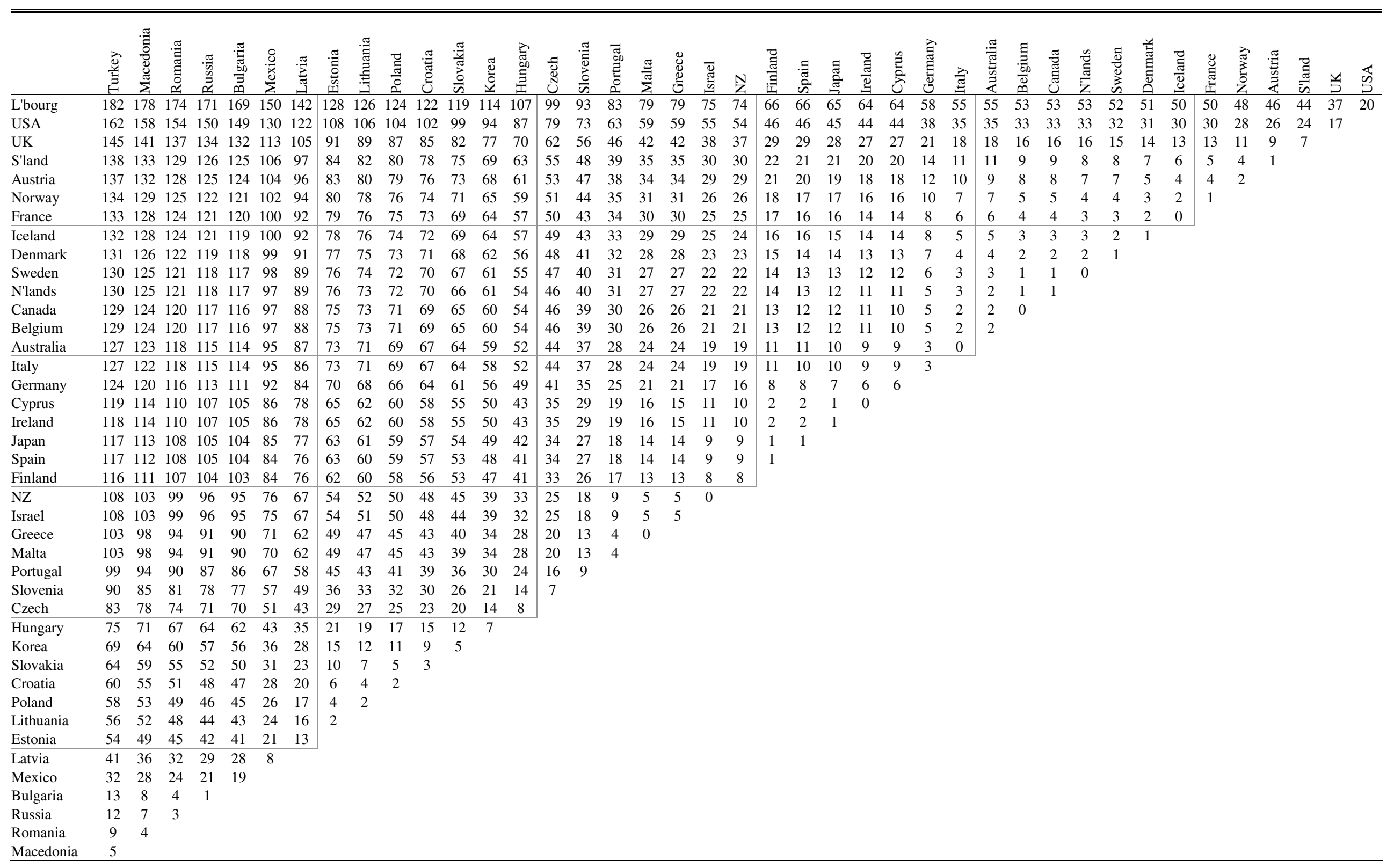


TABLE 4

\section{MATRIX OF RATIOS OF CHANGES IN FOOD BUDGET SHARE TO INCOME CHANGES FOR 42 COUNTRIES}

$$
\Delta \mathrm{w}^{\mathrm{ab}} / \Delta \log \mathrm{Q}^{\mathrm{ab}} \times 100
$$

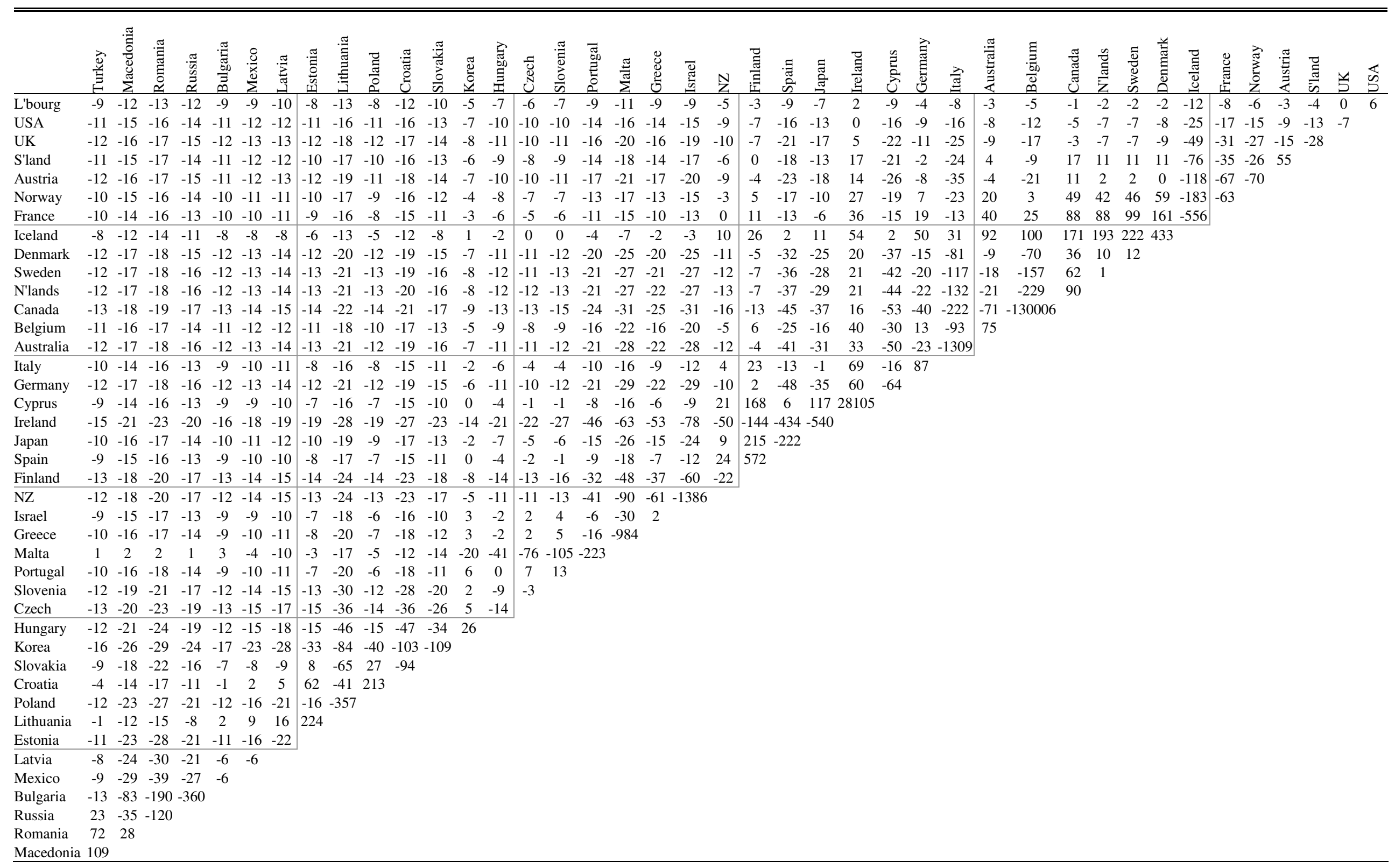


FIGURE 1

\section{RATIOS OF FOOD-BUDGET-SHARE CHANGES \\ TO INCOME CHANGES}

$(\times 100)$
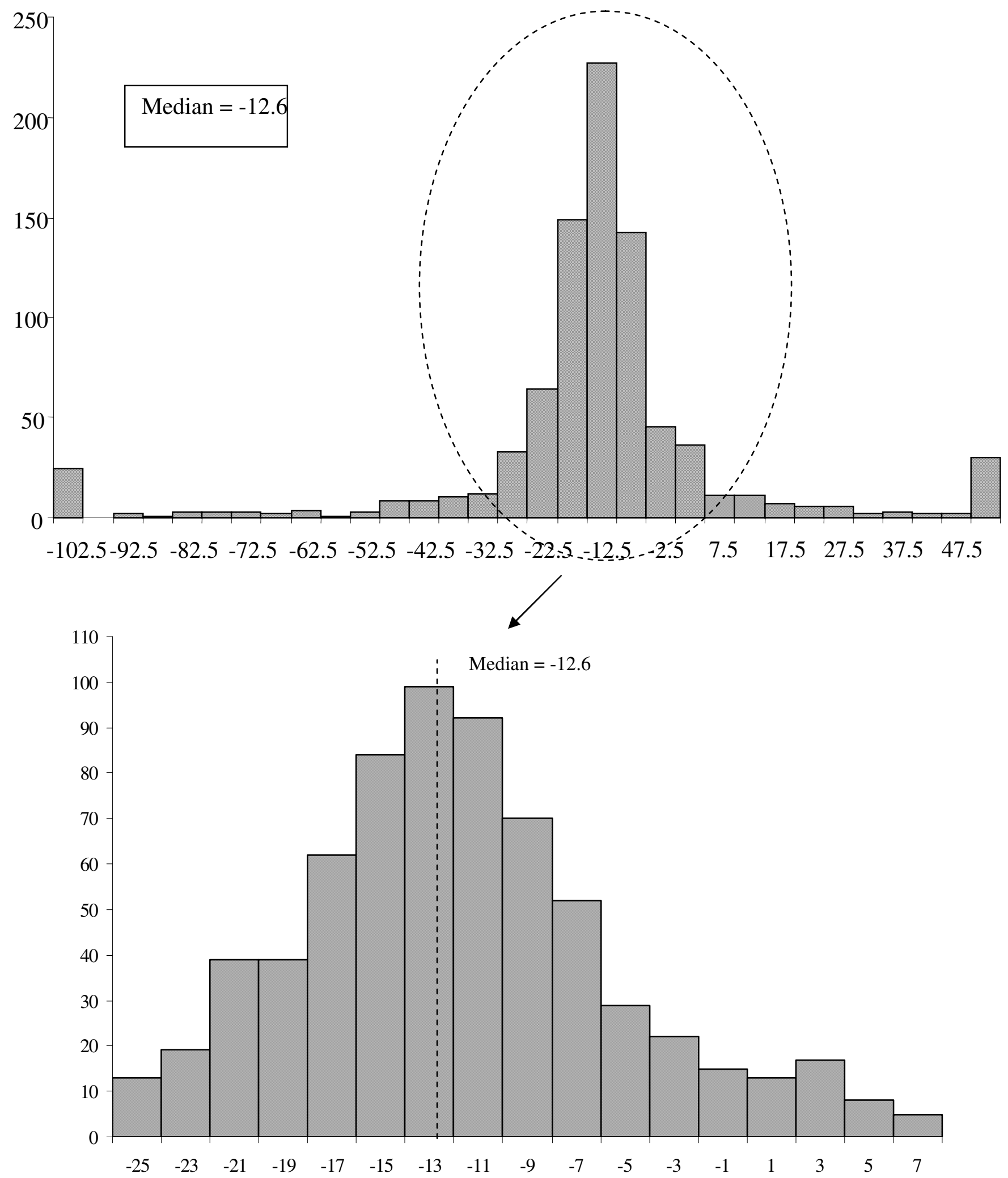

FIGURE 2 


\section{SCATTER OF CHANGES IN FOOD BUDGET SHARE}

\section{AGAINST INCOME CHANGES IN 42 COUNTRIES}

I. All pairs of countries

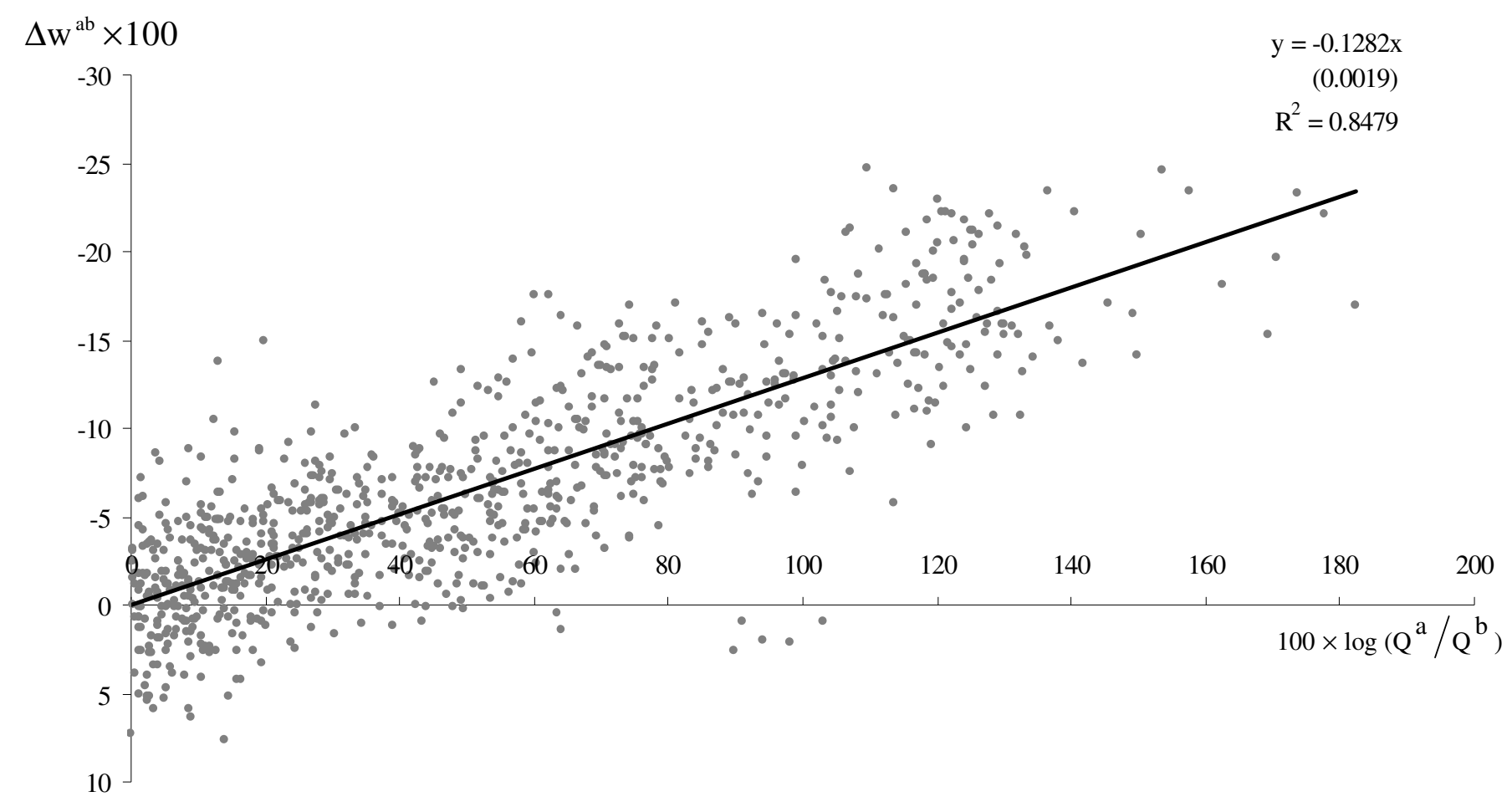

II. Five outlining pairs excluded

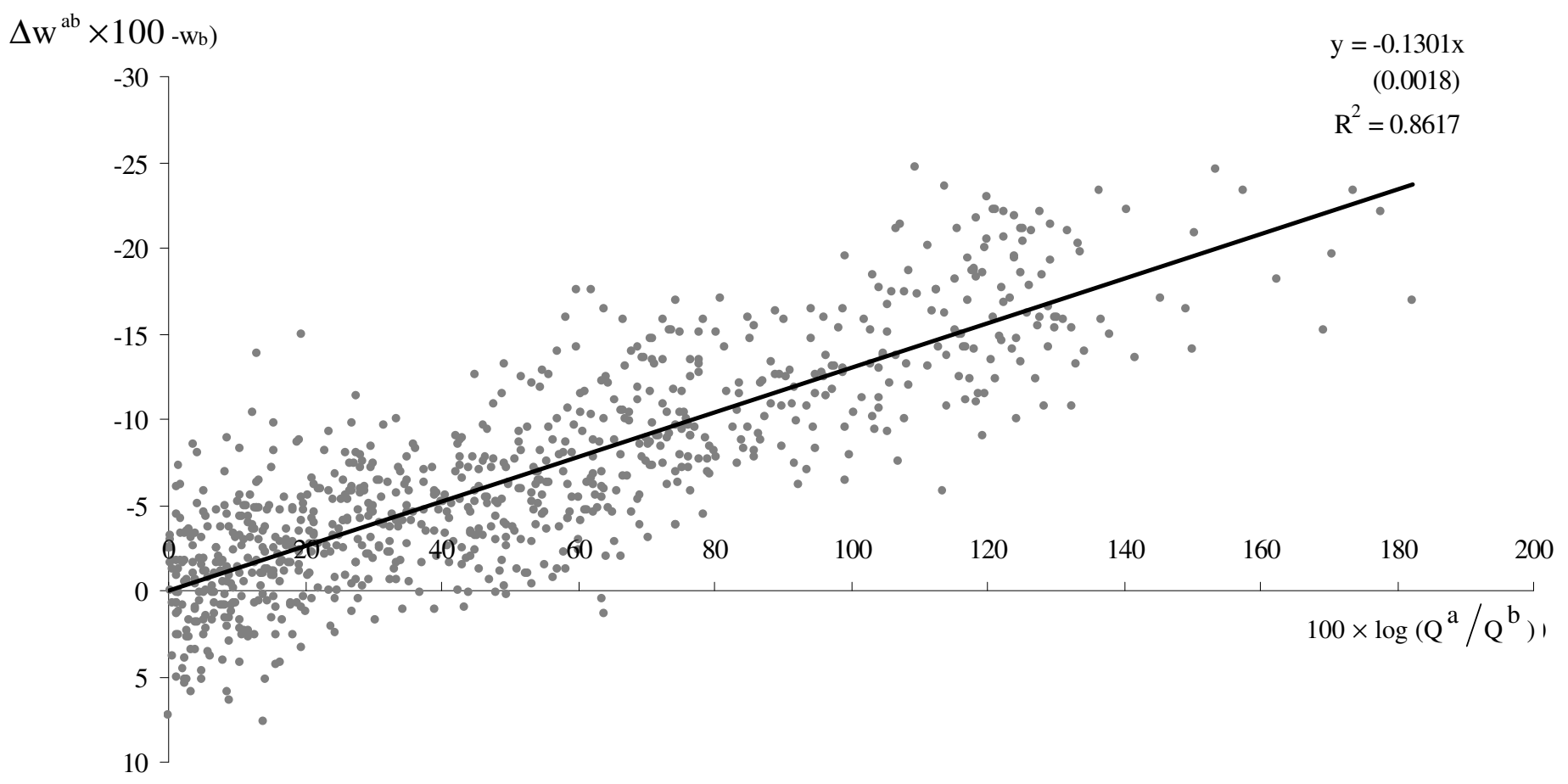

Note: The 5 excluded pairs of countries in panel II are Malta with Turkey, Macedonia, Romania, Russia, and Bulgaria. 
FIGURE 3

SCATTER OF FOOD BUDGET SHARE

AGAINST INCOME

Food budget share $(\times 100)$

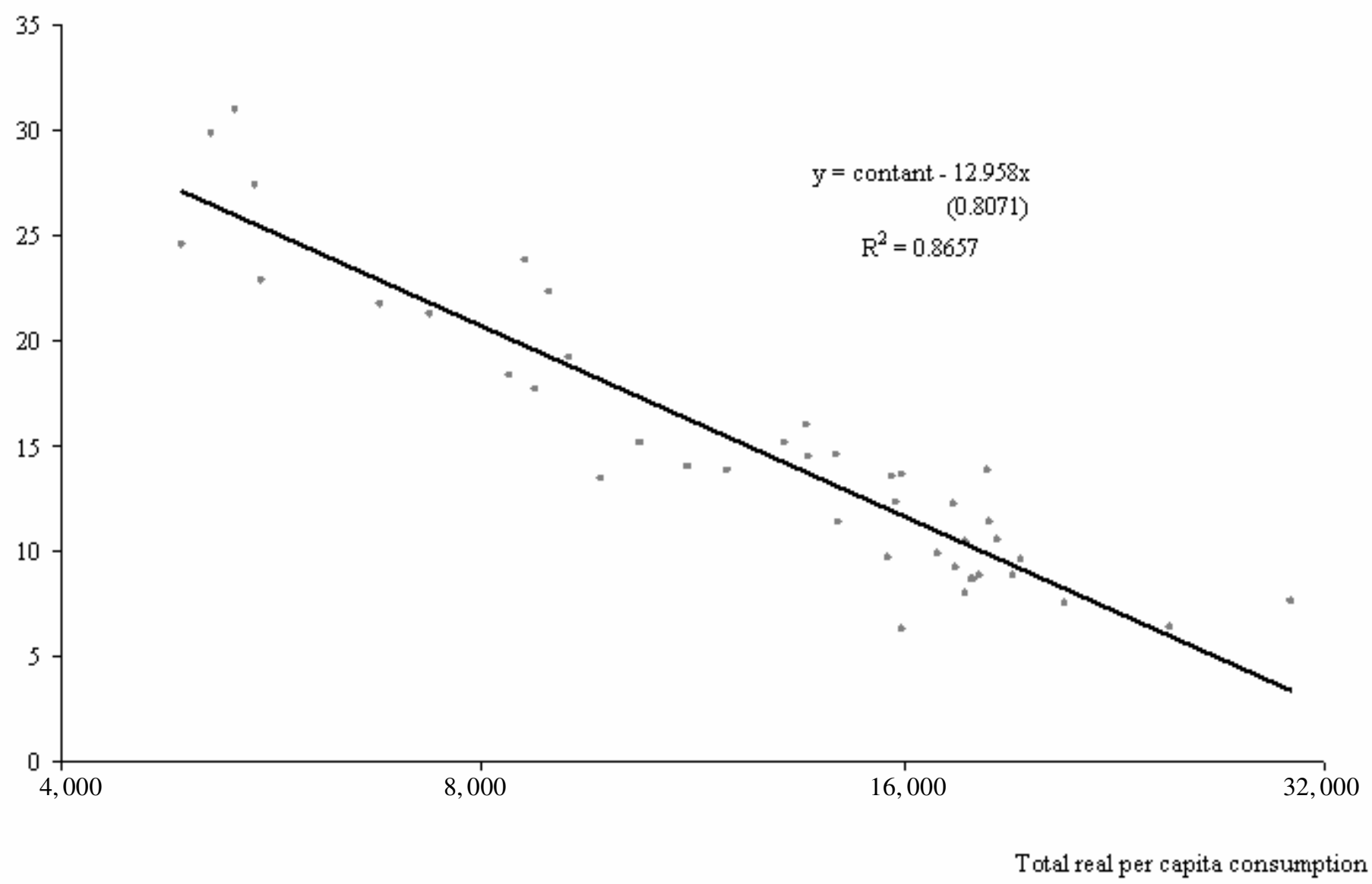




\section{TABLE 5}

THE FLORIDA MODEL: ESTIMATES AND SIMULATION RESULTS

$$
\begin{aligned}
\mathrm{w}_{\mathrm{i}}^{\mathrm{c}}= & \alpha_{\mathrm{i}}+\beta_{\mathrm{i}} \mathrm{q}^{\mathrm{c}}+\left(\alpha_{\mathrm{i}}+\beta_{\mathrm{i}} \mathrm{q}^{\mathrm{c}}\right)\left[\log \frac{\mathrm{p}_{\mathrm{i}}^{\mathrm{c}}}{\overline{\mathrm{p}}_{\mathrm{i}}}-\sum_{\mathrm{j}=1}^{12}\left(\alpha_{\mathrm{j}}+\beta_{\mathrm{j}} \mathrm{q}^{\mathrm{c}}\right) \log \frac{\mathrm{p}_{\mathrm{j}}^{\mathrm{c}}}{\overline{\mathrm{p}}_{\mathrm{j}}}\right] \\
& +\phi\left(\alpha_{\mathrm{i}}+\beta_{\mathrm{i}} \mathrm{q}^{{ }^{\mathrm{c}}}\right)\left[\log \frac{\mathrm{p}_{\mathrm{i}}^{\mathrm{c}}}{\overline{\mathrm{p}}_{\mathrm{i}}}-\sum_{\mathrm{j}=1}^{12}\left(\alpha_{\mathrm{j}}+\beta_{\mathrm{j}} \mathrm{q}^{{ }^{\mathrm{c}}}\right) \log \frac{\mathrm{p}_{\mathrm{j}}^{\mathrm{c}}}{\overline{\mathrm{p}}_{\mathrm{j}}}\right]+\varepsilon_{\mathrm{i}}^{\mathrm{c}}
\end{aligned}
$$

\begin{tabular}{|c|c|c|c|c|c|c|c|c|c|c|}
\hline \multirow{3}{*}{$\begin{array}{c}\text { Commodity } \\
\text { (1) }\end{array}$} & \multicolumn{4}{|c|}{ Data based } & \multicolumn{6}{|c|}{ Monte Carlo simulation } \\
\hline & \multicolumn{2}{|c|}{ Intercept $\alpha_{i}$} & \multicolumn{2}{|c|}{ Slope $\beta_{\mathrm{i}}$} & \multicolumn{3}{|c|}{ Intercept $\alpha_{i}$} & \multicolumn{3}{|c|}{ Slope $\beta_{\mathrm{i}}$} \\
\hline & $\begin{array}{l}\text { Point estimate } \\
\text { (2) }\end{array}$ & $\begin{array}{c}\text { ASE } \\
(3) \\
\end{array}$ & $\begin{array}{l}\text { Point estimate } \\
\text { (4) }\end{array}$ & $\begin{array}{l}\text { ASE } \\
(5) \\
\end{array}$ & $\begin{array}{c}\text { Mean } \\
(6)\end{array}$ & $\begin{array}{c}\text { RMSE } \\
(7)\end{array}$ & $\begin{array}{c}\text { RMASE } \\
(8)\end{array}$ & $\begin{array}{c}\text { Mean } \\
(9) \\
\end{array}$ & $\begin{array}{c}\text { RMSE } \\
(10) \\
\end{array}$ & $\begin{array}{c}\text { RMASE } \\
\text { (11) }\end{array}$ \\
\hline 1. Food & 0.0789 & 0.0051 & -0.1010 & 0.0059 & 0.0792 & 0.0051 & 0.0048 & -0.1008 & 0.0061 & 0.0055 \\
\hline 2. Alcohol \& tobacco & 0.0356 & 0.0042 & -0.0073 & 0.0050 & 0.0356 & 0.0041 & 0.0040 & -0.0073 & 0.0050 & 0.0046 \\
\hline 3. Clothing & 0.0453 & 0.0034 & -0.0039 & 0.0036 & 0.0451 & 0.0035 & 0.0032 & -0.0041 & 0.0038 & 0.0034 \\
\hline 4. Housing & 0.1511 & 0.0097 & -0.0306 & 0.0123 & 0.1515 & 0.0104 & 0.0090 & -0.0301 & 0.0132 & 0.0111 \\
\hline 5. Durables & 0.0553 & 0.0028 & 0.0084 & 0.0031 & 0.0553 & 0.0029 & 0.0026 & 0.0083 & 0.0032 & 0.0029 \\
\hline 6. Health & 0.1184 & 0.0067 & 0.0313 & 0.0094 & 0.1186 & 0.0070 & 0.0063 & 0.0315 & 0.0100 & 0.0086 \\
\hline 7. Transport & 0.1099 & 0.0049 & 0.0090 & 0.0055 & 0.1099 & 0.0051 & 0.0046 & 0.0091 & 0.0056 & 0.0050 \\
\hline 8. Communication & 0.0231 & 0.0019 & -0.0049 & 0.0018 & 0.0230 & 0.0019 & 0.0018 & -0.0049 & 0.0019 & 0.0016 \\
\hline 9. Recreation & 0.0978 & 0.0040 & 0.0301 & 0.0046 & 0.0978 & 0.0042 & 0.0038 & 0.0300 & 0.0048 & 0.0043 \\
\hline 10. Education & 0.0743 & 0.0062 & -0.0019 & 0.0093 & 0.0744 & 0.0067 & 0.0055 & -0.0017 & 0.0105 & 0.0080 \\
\hline 11. Restaurants & 0.0785 & 0.0080 & 0.0219 & 0.0094 & 0.0780 & 0.0082 & 0.0076 & 0.0213 & 0.0098 & 0.0087 \\
\hline 12. Other & 0.1320 & 0.0079 & 0.0488 & 0.0097 & 0.1317 & 0.0081 & 0.0075 & 0.0486 & 0.0100 & 0.0091 \\
\hline Income flexibility & Point esti & ate $=-0.7728$ & $\mathrm{ASE}=0.0533$ & & & Mean $=-0$ & 754 & 0.0619 & RMASE = & 0446 \\
\hline
\end{tabular}

Notes: $1 \cdot \mathrm{q}^{* \mathrm{c}}=1+\mathrm{q}^{\mathrm{c}}$

2. The Monte Carlo simulation involves 1,000 trials.

3. $\mathrm{ASE}=$ asymptotic standard error.

4. RMSE is the root mean squared error over the 1,000 trials.

5. RMASE $=\sqrt{(1 / 1000) \sum_{\mathrm{s}=1}^{1,000}\left(\mathrm{ASE}^{(\mathrm{s})}\right)^{2}}$ where $\mathrm{ASE}^{(\mathrm{s})}$ is the asymptotic SE of a given parameter at trial s. 
TABLE 6

A CROSS-COUNTRY INCOME COMPARISON

\begin{tabular}{|c|c|c|c|c|c|c|c|}
\hline \multirow{3}{*}{$\begin{array}{c}\text { Country } \\
\\
\text { (1) }\end{array}$} & \multicolumn{3}{|c|}{$\log \left(Q^{c} / Q^{*}\right)$} & \multicolumn{4}{|c|}{ Components of simulated $\log \left(\mathrm{Q}^{\mathrm{c}} / \mathrm{Q}^{*}\right)$} \\
\hline & \multirow{2}{*}{$\begin{array}{c}\text { Observed } \\
\text { (2) }\end{array}$} & \multicolumn{2}{|c|}{ Simulated } & \multicolumn{2}{|c|}{ Food share } & \multicolumn{2}{|c|}{ Food relative price } \\
\hline & & $\begin{array}{c}\text { Mean } \\
\text { (3) }\end{array}$ & $\begin{array}{l}\text { SD } \\
(4)\end{array}$ & $\begin{array}{c}\text { Mean } \\
(5)\end{array}$ & $\begin{array}{l}\text { SD } \\
(6)\end{array}$ & $\begin{array}{c}\text { Mean } \\
(7)\end{array}$ & $\begin{array}{l}\text { SD } \\
(8)\end{array}$ \\
\hline 1. L'bourg & 86.6 & 62.6 & 11.5 & 73.1 & 11.6 & -10.6 & 0.7 \\
\hline 2. USA & 66.6 & 42.2 & 10.9 & 73.3 & 11.0 & -31.1 & 2.0 \\
\hline 3. UK & 49.6 & 45.5 & 16.0 & 59.9 & 15.4 & -14.4 & 0.7 \\
\hline 4. S'land & 42.3 & 43.3 & 18.0 & 46.8 & 17.8 & -3.5 & 0.1 \\
\hline 5. Austria & 41.0 & 39.6 & 17.6 & 53.0 & 17.2 & -13.4 & 0.6 \\
\hline 6. Norway & 38.5 & 40.6 & 19.2 & 41.4 & 19.2 & -0.8 & 0.0 \\
\hline 7. France & 37.1 & 38.4 & 19.3 & 40.3 & 19.3 & -1.9 & 0.1 \\
\hline 8. Iceland & 36.7 & 40.2 & 18.9 & 30.4 & 19.2 & 9.7 & 0.4 \\
\hline 9. Denmark & 35.5 & 37.5 & 18.2 & 47.4 & 17.9 & -10.0 & 0.4 \\
\hline 10. Sweden & 34.3 & 36.6 & 17.6 & 46.6 & 17.3 & -9.9 & 0.4 \\
\hline 11. N'lands & 34.0 & 33.5 & 18.3 & 47.4 & 17.8 & -13.9 & 0.6 \\
\hline 12. Canada & 33.2 & 32.5 & 17.8 & 52.5 & 17.1 & -20.0 & 0.9 \\
\hline 13. Belgium & 33.2 & 35.3 & 18.6 & 45.4 & 18.3 & -10.1 & 0.4 \\
\hline 14. Australia & 31.6 & 33.1 & 18.9 & 44.5 & 18.5 & -11.4 & 0.5 \\
\hline 15. Italy & 31.3 & 32.0 & 18.7 & 39.4 & 18.5 & -7.4 & 0.3 \\
\hline 16. Germany & 28.6 & 28.8 & 18.9 & 46.9 & 18.3 & -18.1 & 0.8 \\
\hline 17. Cyprus & 22.7 & 19.7 & 20.0 & 24.4 & 19.8 & -4.7 & 0.2 \\
\hline 18. Ireland & 22.7 & 23.3 & 18.7 & 37.1 & 18.3 & -13.7 & 0.6 \\
\hline 19. Japan & 21.6 & 25.5 & 20.3 & 2.5 & 20.8 & 23.1 & 0.9 \\
\hline 20. Spain & 21.0 & 20.2 & 20.1 & 32.1 & 19.8 & -11.8 & 0.5 \\
\hline 21. Finland & 20.4 & 22.5 & 20.2 & 36.5 & 19.8 & -14.0 & 0.6 \\
\hline 22. NZ & 12.3 & 14.0 & 20.2 & 16.9 & 20.1 & -2.9 & 0.1 \\
\hline 23. Israel & 12.1 & 18.8 & 20.5 & 19.3 & 20.5 & -0.5 & 0.0 \\
\hline 24. Greece & 7.3 & 3.7 & 20.9 & 10.6 & 20.8 & -6.9 & 0.3 \\
\hline 25. Malta & 7.2 & -1.3 & 20.9 & 0.6 & 20.9 & -1.9 & 0.1 \\
\hline 26. Portugal & 3.4 & -2.2 & 21.0 & 1.8 & 21.0 & -4.0 & 0.2 \\
\hline 27. Slovenia & -5.9 & -3.6 & 21.3 & -11.7 & 21.4 & 8.1 & 0.3 \\
\hline 28. Czech & -12.5 & -8.0 & 21.1 & -13.0 & 21.2 & 4.9 & 0.2 \\
\hline 29. Hungary & -20.3 & -19.4 & 20.4 & -32.5 & 20.6 & 13.2 & 0.6 \\
\hline 30. Korea & -27.0 & -20.6 & 20.1 & -44.6 & 20.5 & 24 & 1.1 \\
\hline 31. Slovakia & -32.2 & -28.1 & 20.4 & -48.3 & 20.7 & 20.2 & 0.9 \\
\hline 32. Croatia & -35.5 & -37.3 & 19.7 & -60.0 & 20.1 & 22.7 & 1.1 \\
\hline 33. Poland & -37.7 & -32.2 & 20.4 & -30.2 & 20.4 & -2.0 & 0.1 \\
\hline 34. Lithuania & -39.4 & -40.2 & 19.9 & -54.4 & 20.1 & 14.3 & 0.7 \\
\hline 35. Estonia & -41.8 & -37.1 & 20.1 & -55.0 & 20.3 & 17.9 & 0.8 \\
\hline 36. Latvia & -55.1 & -49.4 & 18.9 & -70.6 & 19.2 & 21.2 & 1.0 \\
\hline 37. Mexico & -63.3 & -53.9 & 20.4 & -41.2 & 20.2 & -12.7 & 0.6 \\
\hline 38. Bulgaria & -82.6 & -81.9 & 17.8 & -110.2 & 18.3 & 28.3 & 1.5 \\
\hline 39. Russia & -83.9 & -100.4 & 17.2 & -114.4 & 17.4 & 14.1 & 0.8 \\
\hline 40. Romania & -86.9 & -86.4 & 17.3 & -109.9 & 17.7 & 23.5 & 1.2 \\
\hline 41. Macedonia & -91.0 & -90.7 & 16.7 & -109.2 & 16.9 & 18.5 & 1.0 \\
\hline 42. Turkey & -95.8 & -91.3 & 17.0 & -111.9 & 17.3 & 20.7 & 1.1 \\
\hline
\end{tabular}

Notes: $1 . \quad$ All entries are to be divided by 100 . 
2. $\mathrm{Q}^{*}=$ geometric mean of $\mathrm{Q}^{\mathrm{c}}$

3. $\mathrm{SD}=$ standard deviation.

FIGURE 4

ACTUAL AND PREDICTED INCOME

$($ Logarithms $\times 100)$

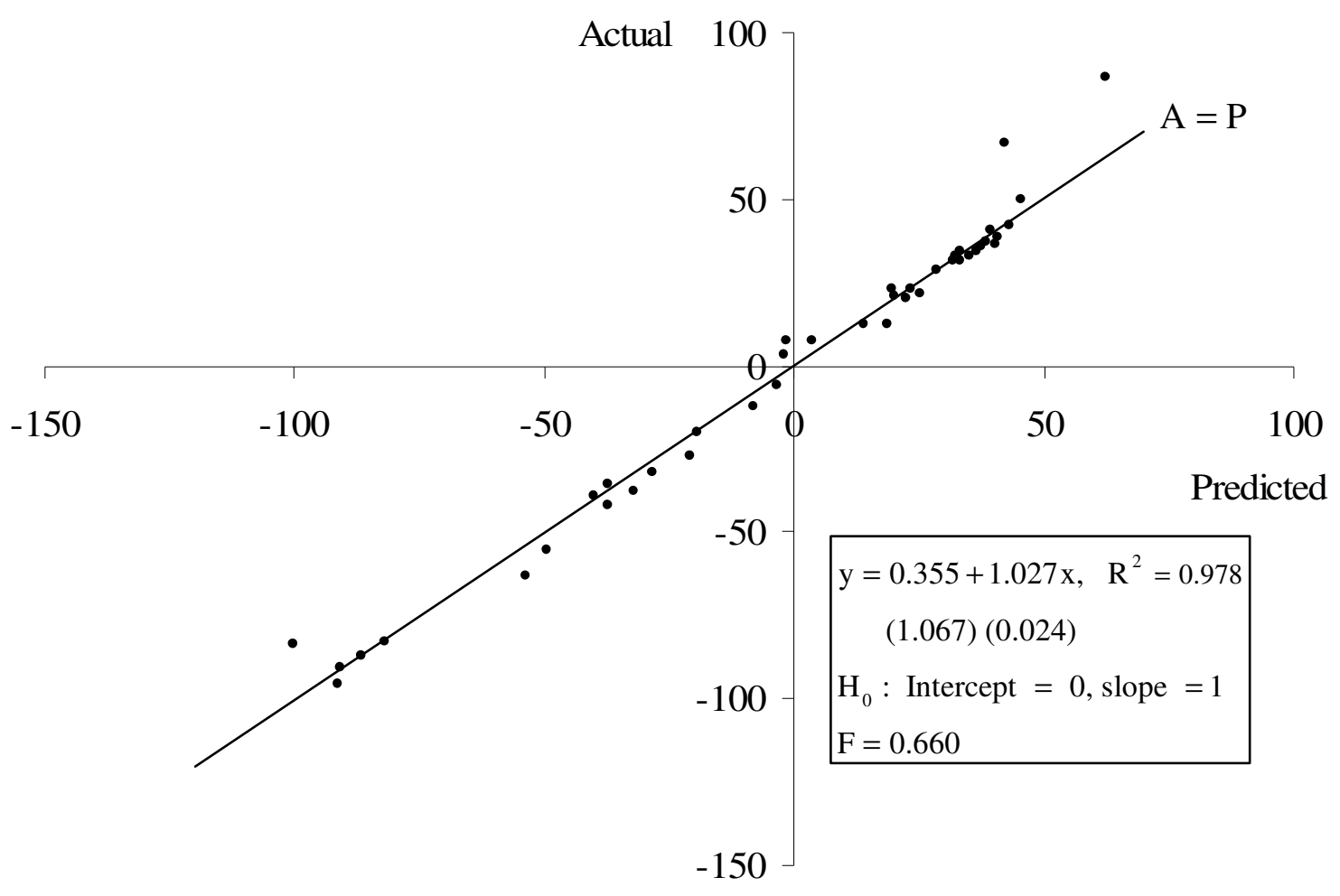




\section{FIGURE 5}

OBSERVED AND SIMULATED CROSS-COUNTRY INCOME COMPARISONS

\section{Observed}

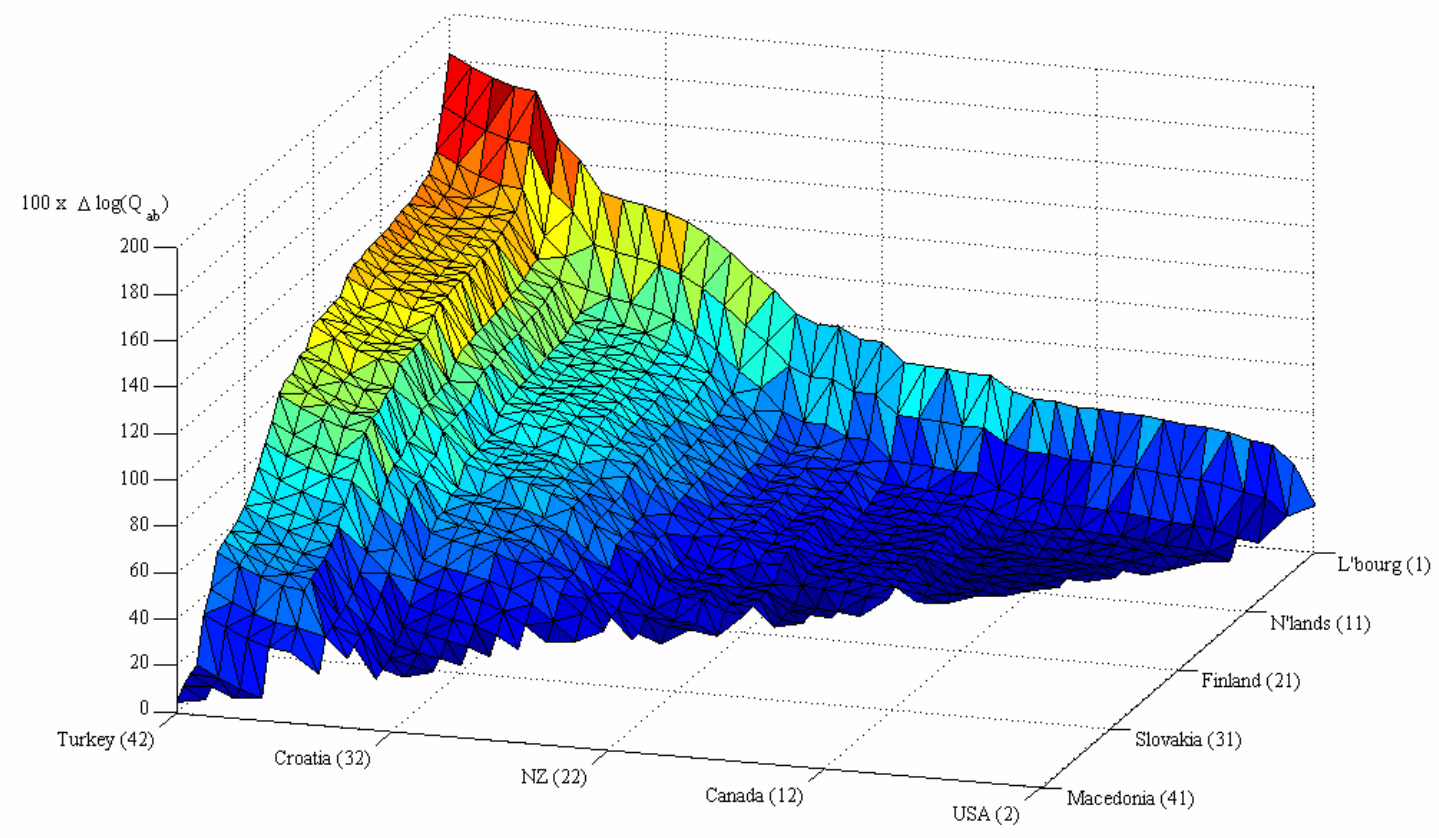

II. Simulated

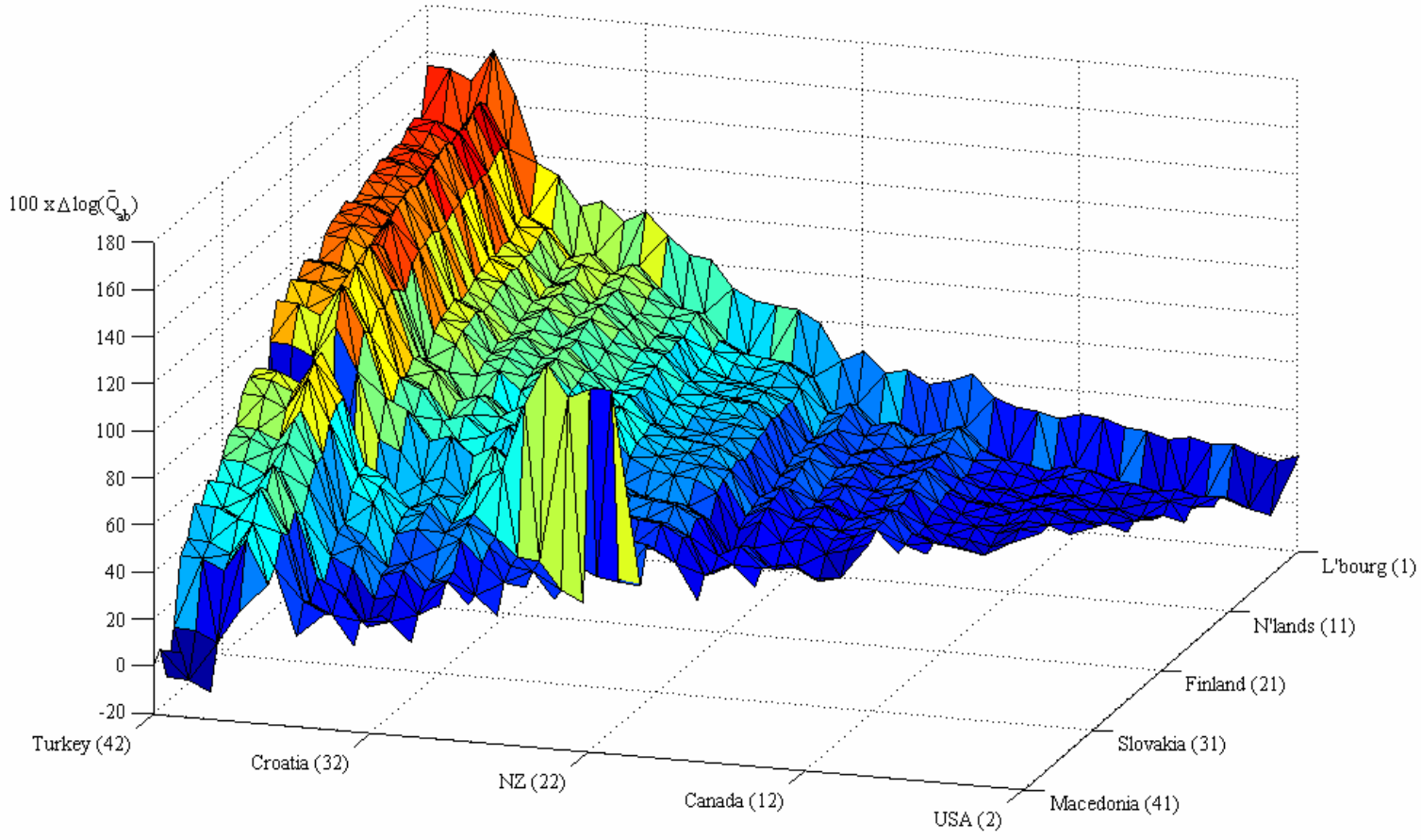




\section{FIGURE 6}

\section{TWO MEASURES OF INCOME DIFFERENCES}

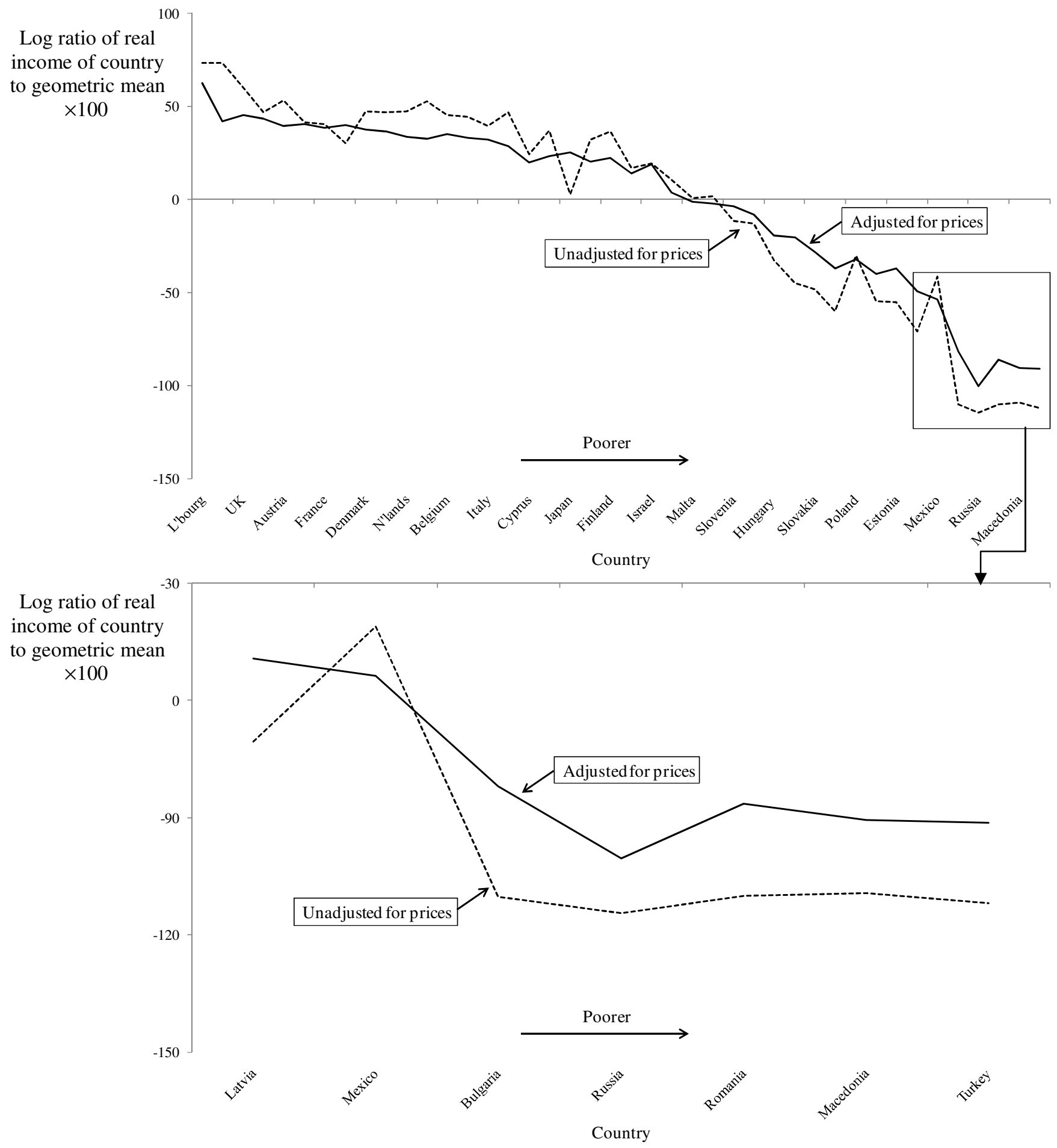


FIGURE 7

MATRIX OF HISTOGRAMS OF SIMULATED INCOME DIFFERENCES FOR SIX COUNTRY GROUPS

(Logarithmic ratios $\times 100)$

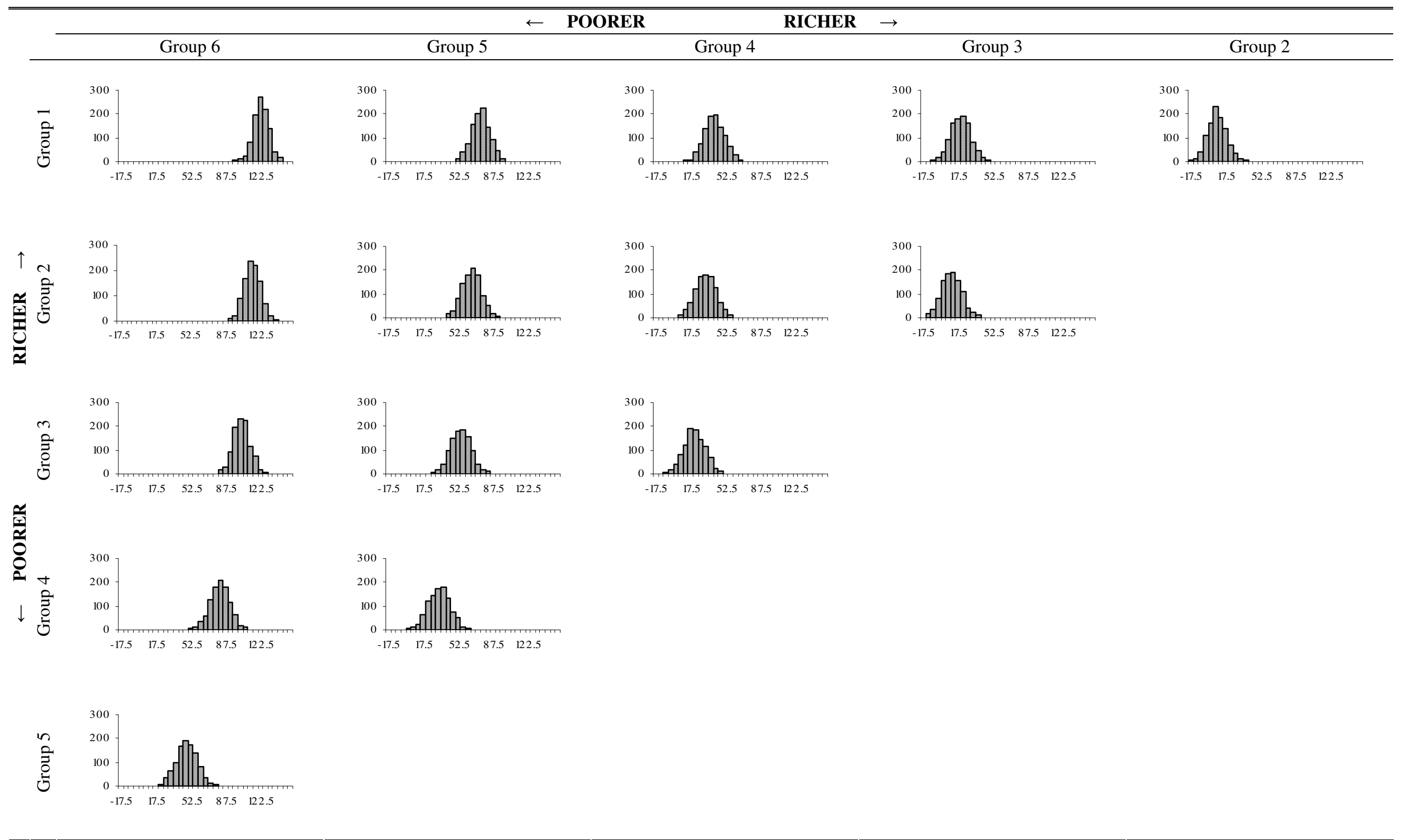


TABLE 7

SIMULATED INCOME DIFFERENCES FOR

SIX COUTNRY GROUPS

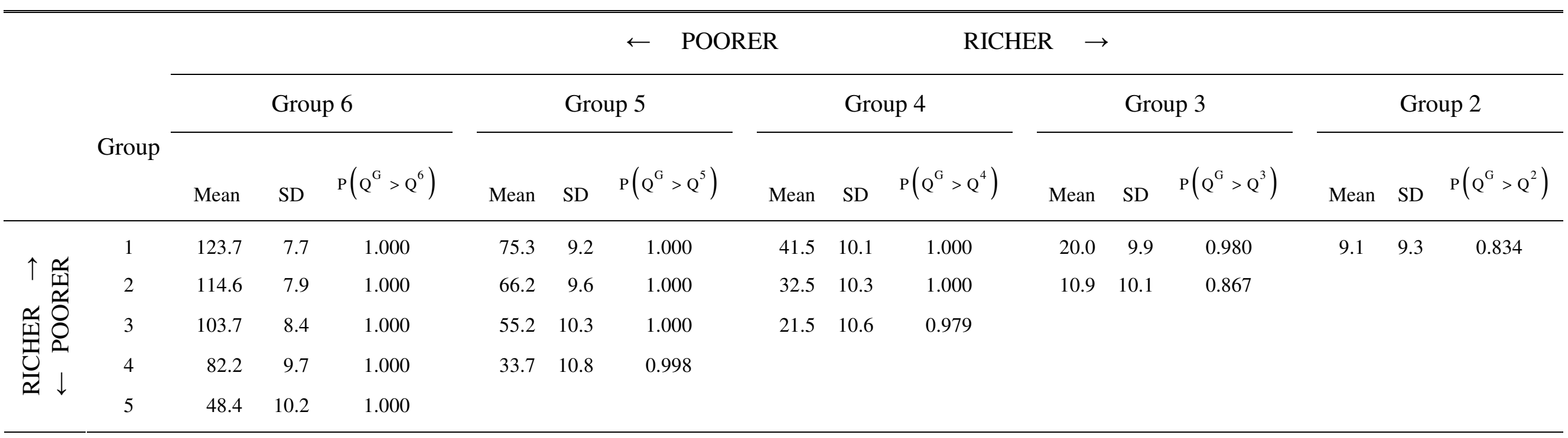

Notes: $1 . \quad \mathrm{SD}=$ standard deviation.

2. In all cases, the underlying variable is the logarithmic ratio of real incomes $\times 100$.

3. $P\left(Q^{\mathrm{G}}>\mathrm{Q}^{\mathrm{H}}\right)$ is the probability that income of country group $\mathrm{G}$ exceeds that of $\mathrm{H}$, for $\mathrm{G}<\mathrm{H}, \mathrm{G}=1, \ldots, 5$, and $\mathrm{H}=2, \ldots, 6$. 


\section{FIGURE 8}

\section{PROBABILITY OF INCOME DIFFERENCES}

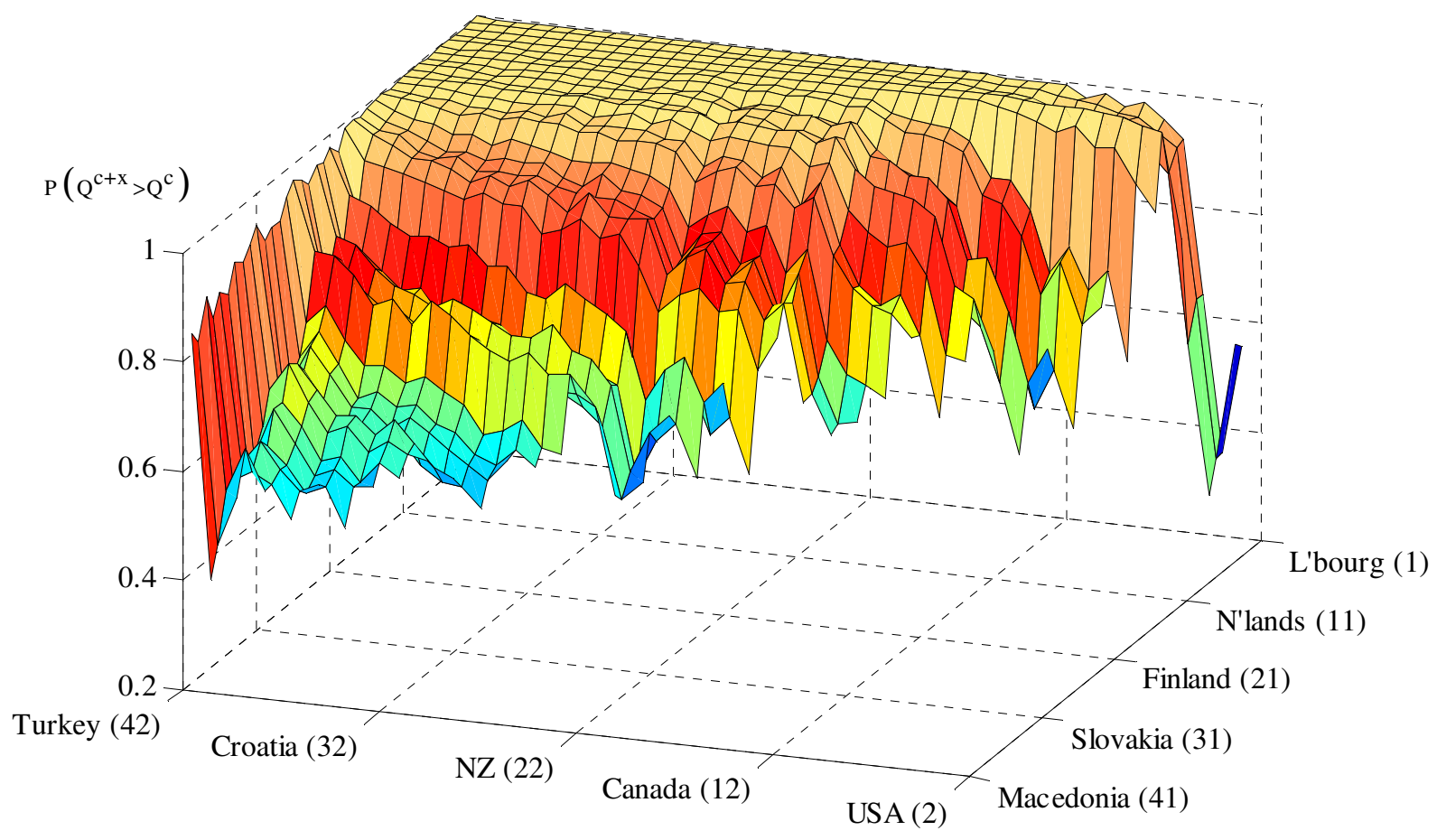


TABLE 8

PROBABILITY OF INCOME DIFFERENCES BY DISTANCE BETWEEN COUNTRIES

\begin{tabular}{|c|c|c|}
\hline \multirow{2}{*}{$\begin{array}{l}\text { Distance as measured } \\
\text { by band width } \\
\text { (Number of countries) }\end{array}$} & \multicolumn{2}{|c|}{ Probability that country $\mathrm{c}$ is richer than $\mathrm{c}+\mathrm{x}$} \\
\hline & Marginal & Cumulative \\
\hline $\mathrm{x}$ & $P\left(Q^{c}>Q^{c+x}\right)$ & $\sum_{y=0}^{x} P\left(Q^{c}>Q^{c+y}\right)$ \\
\hline$(1)$ & $(2)$ & (3) \\
\hline 0 & 0.000 & 0.000 \\
\hline 1 & 0.553 & 0.273 \\
\hline 2 & 0.594 & 0.377 \\
\hline 3 & 0.633 & 0.439 \\
\hline 4 & 0.682 & 0.485 \\
\hline 5 & 0.719 & 0.522 \\
\hline 6 & 0.747 & 0.551 \\
\hline 7 & 0.777 & 0.577 \\
\hline 8 & 0.799 & 0.599 \\
\hline 9 & 0.823 & 0.619 \\
\hline 10 & 0.836 & 0.636 \\
\hline 11 & 0.856 & 0.651 \\
\hline 12 & 0.872 & 0.666 \\
\hline 13 & 0.887 & 0.679 \\
\hline 14 & 0.904 & 0.691 \\
\hline 15 & 0.918 & 0.702 \\
\hline 16 & 0.925 & 0.712 \\
\hline 17 & 0.934 & 0.721 \\
\hline 18 & 0.945 & 0.730 \\
\hline 19 & 0.956 & 0.738 \\
\hline 20 & 0.967 & 0.745 \\
\hline 21 & 0.972 & 0.752 \\
\hline 22 & 0.980 & 0.758 \\
\hline 23 & 0.987 & 0.764 \\
\hline 24 & 0.989 & 0.770 \\
\hline 25 & 0.992 & 0.775 \\
\hline 26 & 0.996 & 0.779 \\
\hline 27 & 0.997 & 0.783 \\
\hline 28 & 0.999 & 0.787 \\
\hline 29 & 0.999 & 0.79 \\
\hline 30 & 0.999 & 0.793 \\
\hline 31 & 1.000 & 0.796 \\
\hline 32 & 1.000 & 0.798 \\
\hline 33 & 1.000 & 0.800 \\
\hline 34 & 1.000 & 0.802 \\
\hline 35 & 1.000 & 0.804 \\
\hline 36 & 1.000 & 0.805 \\
\hline 37 & 1.000 & 0.806 \\
\hline 38 & 1.000 & 0.807 \\
\hline 39 & 1.000 & 0.808 \\
\hline 40 & 1.000 & 0.808 \\
\hline 41 & 1.000 & 0.808 \\
\hline
\end{tabular}

Notes:

1. Countries are indexed by $\mathrm{c}=1, \ldots, 42$ and ranked in terms of decreasing per capita income. Column 2 gives the relative frequency that country $\mathrm{c}$ is richer than country $\mathrm{c}+\mathrm{x}$ ( $\mathrm{x} \geq 0$, the "band width"), for $\mathrm{c}=1, \ldots, 42$. Alternatively, in the 1,000 realisations of the $42 \times 42$ matrix $\mathbf{Q}^{(\mathrm{s})}=\left[\mathrm{Q}^{\mathrm{a}(\mathrm{s})}-\mathrm{Q}^{\mathrm{b}(\mathrm{s})}\right], \mathrm{s}=1, \ldots, 1,000$, the entry in column 2 corresponding to band width $\mathrm{x}$, is the average of the relative frequencies on the sub diagonal $\mathrm{x}$ steps away from the main diagonal once removed.

2. Column 3 gives the relative frequencies of positive values contained in the bands of $\mathbf{Q}^{(\mathrm{s})}, \mathrm{s}=1, \ldots, 1,000, \mathrm{x}$ steps away from the main diagonal once removed. 
TABLE 9

\section{COMPARISON OF ROMANIA AND FRANCE}

\begin{tabular}{ccc}
\hline \hline Concept & Observed & Price \\
$(1)$ & $(2)$ & adjusted \\
& & $(3)$ \\
\hline
\end{tabular}

Ratio offood shares:

$$
\begin{aligned}
& \mathrm{w}^{\mathrm{R}} / \mathrm{w}^{\mathrm{F}} \\
& \exp \left\{\log \left(\frac{\mathrm{w}^{\mathrm{R}}}{\mathrm{w}^{\mathrm{F}}}\right)-\Delta \log \left(\frac{\mathrm{w}^{\mathrm{R}}}{\mathrm{w}^{\mathrm{F}}}\right)\right\}
\end{aligned}
$$

Estimated income difference:

$$
\begin{aligned}
& \frac{1}{\eta^{\mathrm{RF}}-1} \log \left(\frac{\mathrm{w}^{\mathrm{R}}}{\mathrm{w}^{\mathrm{F}}}\right) \\
& \frac{1}{\eta^{\mathrm{RF}}-1}\left\{\log \left(\frac{\mathrm{w}^{\mathrm{R}}}{\mathrm{w}^{\mathrm{F}}}\right)-\Delta \log \left(\frac{\mathrm{w}^{\mathrm{R}}}{\mathrm{w}^{\mathrm{F}}}\right)\right\}
\end{aligned}
$$

Percentage difference

$-81 \%$

$-76 \%$ 
TABLE A1

\section{BUDGET SHARES OF 12 GOODS IN 42 COUNTRIES}

(Percentages)

\begin{tabular}{|c|c|c|c|c|c|c|c|c|c|c|c|c|}
\hline $\begin{array}{c}\text { Country } \\
\text { (1) }\end{array}$ & $\begin{array}{l}\overline{8} \\
8 \\
0 \\
(2) \\
\end{array}$ & 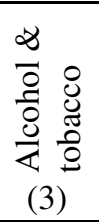 & 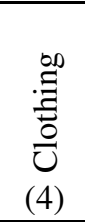 & 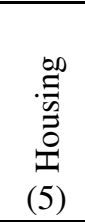 & 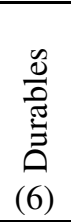 & 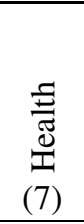 & 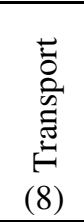 & 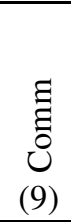 & 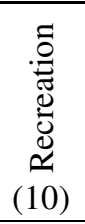 & 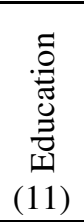 & 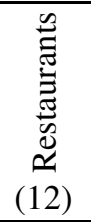 & $\begin{array}{c}\bar{\Xi} \\
\stackrel{ \pm}{0} \\
(13)\end{array}$ \\
\hline 1. L'bourg & 7.7 & 9.4 & 3.8 & 17.3 & 6.5 & 7.6 & 14.7 & 1.4 & 8.1 & 7.2 & 6.0 & 10.1 \\
\hline 2. USA & 6.4 & 2.0 & 4.3 & 16.4 & 4.4 & 17.8 & 10.5 & 1.7 & 8.5 & 8.5 & 5.5 & 13.8 \\
\hline 3. UK & 7.6 & 3.2 & 4.9 & 14.7 & 4.9 & 9.2 & 11.7 & 1.8 & 10.7 & 5.7 & 9.5 & 16.1 \\
\hline 4. S'land & 9.6 & 3.2 & 3.7 & 20.7 & 4.1 & 12.8 & 7.0 & 2.0 & 8.7 & 7.7 & 6.8 & 13.8 \\
\hline 5. Austria & 8.8 & 2.4 & 5.5 & 16.1 & 6.6 & 9.7 & 10.6 & 2.1 & 9.6 & 8.0 & 9.7 & 10.9 \\
\hline 6. Norway & 10.6 & 3.4 & 4.3 & 15.4 & 4.7 & 13.6 & 10.8 & 2.1 & 11.3 & 8.2 & 4.7 & 10.9 \\
\hline 7. France & 11.4 & 2.7 & 3.7 & 19.5 & 4.8 & 12.9 & 11.7 & 1.8 & 8.0 & 6.8 & 6.0 & 10.8 \\
\hline 8. Iceland & 13.9 & 3.6 & 4.2 & 14.9 & 5.3 & 14.1 & 8.7 & 0.9 & 10.0 & 8.7 & 6.4 & 9.1 \\
\hline 9. Denmark & 8.8 & 3.1 & 3.6 & 20.2 & 4.1 & 10.1 & 8.5 & 1.5 & 9.1 & 9.7 & 3.8 & 17.4 \\
\hline 10. Sweden & 8.7 & 2.9 & 3.9 & 19.8 & 3.5 & 11.2 & 8.9 & 2.3 & 10.1 & 10.0 & 3.5 & 15.1 \\
\hline 11. N'lands & 8.7 & 2.4 & 4.6 & 16.7 & 5.6 & 10.4 & 9.4 & 3.1 & 9.6 & 7.1 & 4.5 & 17.8 \\
\hline 12. Canada & 8.0 & 3.3 & 4.2 & 19.3 & 5.4 & 12.0 & 12.1 & 1.8 & 9.6 & 7.9 & 6.1 & 10.3 \\
\hline 13. Belgium & 10.4 & 2.9 & 4.3 & 18.2 & 4.4 & 12.3 & 11.0 & 1.8 & 8.0 & 9.4 & 4.2 & 13.0 \\
\hline 14. Australia & 9.2 & 3.7 & 3.4 & 17.9 & 5.2 & 12.2 & 10.1 & 2.4 & 10.6 & 6.8 & 6.8 & 11.6 \\
\hline 15. Italy & 12.2 & 2.0 & 7.7 & 16.5 & 7.4 & 10.9 & 9.9 & 2.5 & 6.8 & 7.0 & 8.1 & 8.8 \\
\hline 16. Germany & 9.8 & 3.2 & 4.9 & 20.0 & 5.4 & 12.5 & 11.7 & 2.3 & 8.2 & 5.8 & 3.8 & 12.3 \\
\hline 17. Cyprus & 13.6 & 4.3 & 6.4 & 11.8 & 5.9 & 5.4 & 13.3 & 2.2 & 7.5 & 6.2 & 11.7 & 11.7 \\
\hline 18. Ireland & 6.3 & 5.2 & 4.9 & 17.3 & 5.6 & 9.7 & 8.3 & 2.1 & 6.2 & 9.9 & 13.8 & 10.8 \\
\hline 19. Japan & 12.3 & 2.5 & 3.9 & 22.0 & 3.7 & 12.3 & 8.9 & 2.3 & 7.9 & 6.4 & 6.2 & 11.6 \\
\hline 20. Spain & 13.5 & 2.7 & 5.3 & 12.2 & 4.9 & 9.7 & 10.3 & 2.3 & 7.7 & 6.7 & 16.5 & 8.1 \\
\hline 21. Finland & 9.6 & 4.4 & 3.5 & 19.2 & 3.7 & 11.1 & 9.2 & 2.5 & 9.7 & 8.3 & 4.9 & 13.9 \\
\hline 22. NZ & 11.4 & 4.1 & 4.0 & 18.5 & 5.3 & 9.4 & 11.6 & 2.5 & 11.6 & 6.7 & 6.6 & 8.3 \\
\hline 23. Israel & 14.6 & 2.1 & 2.7 & 20.9 & 5.8 & 10.2 & 7.8 & 3.2 & 6.9 & 12.4 & 3.0 & 10.3 \\
\hline 24. Greece & 14.5 & 4.3 & 9.5 & 14.4 & 5.9 & 8.1 & 7.3 & 2.6 & 5.5 & 6.3 & 15.9 & 5.6 \\
\hline 25. Malta & 16.0 & 3.1 & 5.1 & 7.9 & 7.7 & 7.7 & 12.2 & 4.1 & 8.7 & 7.5 & 12.0 & 7.8 \\
\hline 26. Portugal & 15.1 & 3.3 & 5.8 & 8.8 & 5.9 & 11.3 & 13.7 & 3.0 & 6.7 & 8.9 & 8.0 & 9.7 \\
\hline 27. Slovenia & 13.9 & 3.8 & 5.1 & 16.3 & 5.0 & 10.9 & 12.0 & 2.2 & 8.8 & 8.2 & 5.3 & 8.4 \\
\hline 28. Czech & 14.1 & 7.1 & 4.3 & 18.5 & 4.4 & 10.6 & 8.2 & 2.4 & 10.7 & 7.1 & 5.4 & 7.1 \\
\hline 29. Hungary & 15.1 & 6.8 & 3.5 & 14.4 & 5.4 & 11.1 & 12.0 & 4.1 & 7.8 & 7.9 & 3.9 & 7.9 \\
\hline 30. Korea & 13.4 & 2.1 & 4.1 & 14.4 & 3.9 & 4.1 & 10.3 & 5.2 & 7.5 & 9.4 & 6.7 & 18.9 \\
\hline 31. Slovakia & 19.2 & 4.8 & 3.7 & 20.0 & 4.5 & 9.1 & 8.0 & 3.3 & 9.0 & 5.8 & 6.5 & 6.1 \\
\hline 32. Croatia & 22.3 & 5.4 & 5.7 & 16.5 & 4.5 & 6.7 & 11.5 & 2.7 & 4.8 & 6.5 & 6.3 & 7.4 \\
\hline 33. Poland & 17.7 & 5.7 & 4.0 & 21.5 & 3.9 & 8.7 & 9.2 & 2.8 & 6.7 & 7.6 & 2.6 & 9.6 \\
\hline 34. Lithuania & 23.8 & 5.9 & 5.1 & 14.4 & 4.3 & 9.2 & 11.6 & 2.8 & 6.4 & 7.7 & 2.8 & 6.1 \\
\hline 35. Estonia & 18.4 & 7.9 & 5.2 & 19.9 & 4.1 & 6.7 & 9.5 & 2.5 & 7.3 & 8.2 & 4.6 & 5.8 \\
\hline 36. Latvia & 21.3 & 6.6 & 6.4 & 18.5 & 2.6 & 8.6 & 7.8 & 3.1 & 8.0 & 8.7 & 4.0 & 4.2 \\
\hline 37. Mexico & 21.7 & 2.4 & 3.1 & 11.9 & 7.5 & 7.0 & 15.3 & 1.5 & 3.0 & 8.9 & 7.0 & 10.8 \\
\hline 38. Bulgaria & 22.9 & 2.8 & 3.2 & 20.5 & 2.9 & 7.0 & 13.8 & 5.3 & 4.8 & 5.6 & 7.6 & 3.5 \\
\hline 39. Russia & 27.3 & 7.4 & 10.9 & 6.8 & 4.6 & 8.2 & 9.3 & 3.2 & 4.9 & 7.0 & 2.4 & 7.9 \\
\hline 40. Romania & 31.0 & 4.8 & 3.2 & 20.7 & 3.7 & 6.9 & 10.2 & 2.7 & 4.9 & 4.0 & 4.3 & 3.6 \\
\hline 41. Macedonia & 29.8 & 3.6 & 5.5 & 16.4 & 3.9 & 7.9 & 10.2 & 5.2 & 2.7 & 5.2 & 3.4 & 6.2 \\
\hline 42. Turkey & 24.6 & 3.8 & 5.8 & 25.5 & 6.8 & 3.6 & 8.2 & 4.2 & 2.4 & 5.6 & 4.2 & 5.3 \\
\hline
\end{tabular}


TABLE A2

PPP PRICES OF 12 COMMODITIES IN 42 COUNTRIES

(Domestic-currency cost of a US dollar's worth of each good)

\begin{tabular}{|c|c|c|c|c|c|c|c|c|c|c|c|c|}
\hline $\begin{array}{c}\text { Country } \\
(1)\end{array}$ & $\begin{array}{l}\nabla \\
8 \\
1 \\
(2) \\
\end{array}$ & 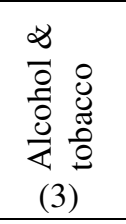 & $\begin{array}{l}\stackrel{0}{\Xi} \\
\stackrel{\Xi}{\Xi} \\
0 \\
(4)\end{array}$ & 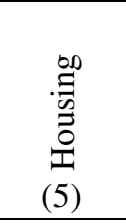 & 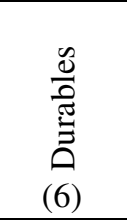 & 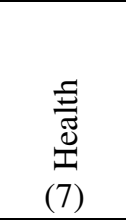 & 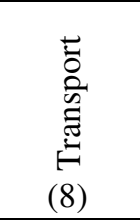 & $\begin{array}{c}\tilde{\Xi} \\
\text { ठี } \\
(9)\end{array}$ & 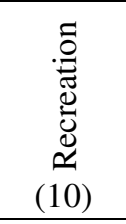 & 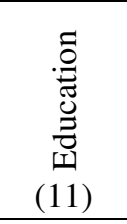 & 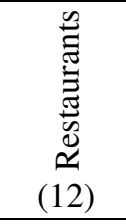 & $\begin{array}{c}\bar{\Xi} \\
\stackrel{\Xi}{0} \\
(13) \\
\end{array}$ \\
\hline 1. L'bourg & 1.07 & 0.82 & 1.29 & 1.12 & 1.10 & 0.84 & 1.08 & 0.81 & 1.16 & 1.32 & 1.04 & 1.00 \\
\hline 2. USA & 0.95 & 1.02 & 0.95 & 1.17 & 1.05 & 1.59 & 0.87 & 0.99 & 0.95 & 1.88 & 0.97 & 1.07 \\
\hline 3. UK & 0.67 & 1.22 & 0.58 & 0.48 & 0.77 & 0.48 & 0.93 & 0.78 & 0.75 & 0.59 & 0.80 & 0.66 \\
\hline 4. S'land & 2.24 & 1.67 & 1.86 & 2.34 & 1.81 & 1.67 & 2.11 & 1.74 & 2.25 & 1.84 & 2.22 & 1.92 \\
\hline 5. Austria & 1.01 & 0.99 & 1.17 & 0.83 & 1.09 & 0.77 & 1.33 & 1.06 & 1.16 & 0.86 & 1.06 & 1.09 \\
\hline 6. Norway & 12.04 & 20.12 & 10.34 & 7.52 & 10.15 & 8.24 & 15.53 & 8.86 & 12.55 & 8.29 & 13.44 & 11.39 \\
\hline 7. France & 1.09 & 1.05 & 1.00 & 1.07 & 0.96 & 0.67 & 1.17 & 1.20 & 1.09 & 0.68 & 0.98 & 0.96 \\
\hline 8. Iceland & 134.00 & 177.90 & 113.70 & 79.40 & 115.90 & 77.50 & 128.50 & 69.10 & 142.50 & 74.70 & 152.90 & 106.90 \\
\hline 9. Denmark & 9.70 & 10.71 & 9.09 & 8.82 & 8.82 & 7.07 & 13.37 & 7.37 & 10.45 & 7.80 & 10.92 & 9.87 \\
\hline 10. Sweden & 10.56 & 13.51 & 10.98 & 9.60 & 11.68 & 7.59 & 13.57 & 7.25 & 11.93 & 7.98 & 11.56 & 10.86 \\
\hline 11. N'lands & 0.98 & 0.98 & 1.17 & 1.02 & 1.05 & 0.68 & 1.34 & 0.94 & 1.02 & 0.76 & 1.05 & 0.96 \\
\hline 12. Canada & 1.33 & 2.09 & 1.51 & 1.33 & 1.62 & 1.18 & 1.46 & 1.04 & 1.62 & 1.44 & 1.55 & 1.36 \\
\hline 13. Belgium & 1.00 & 0.95 & 1.20 & 0.92 & 0.99 & 0.75 & 1.16 & 1.15 & 1.07 & 0.81 & 1.02 & 1.00 \\
\hline 14. Australia & 1.54 & 2.28 & 1.67 & 1.54 & 1.56 & 1.05 & 1.69 & 1.44 & 1.73 & 1.22 & 1.55 & 1.54 \\
\hline 15. Italy & 1.00 & 0.89 & 1.09 & 0.77 & 1.03 & 0.77 & 1.14 & 1.23 & 1.11 & 0.71 & 1.05 & 0.91 \\
\hline 16. Germany & 1.01 & 0.92 & 1.16 & 1.06 & 1.02 & 0.85 & 1.32 & 1.00 & 1.12 & 1.05 & 0.93 & 1.06 \\
\hline 17. Cyprus & 0.56 & 0.66 & 0.57 & 0.35 & 0.55 & 0.40 & 0.65 & 0.37 & 0.60 & 0.39 & 0.65 & 0.45 \\
\hline 18. Ireland & 1.14 & 1.74 & 0.90 & 1.27 & 1.08 & 0.79 & 1.41 & 1.08 & 1.21 & 0.85 & 1.34 & 1.07 \\
\hline 19. Japan & 0.24 & 0.13 & 0.17 & 0.21 & 0.16 & 0.11 & 0.16 & 0.15 & 0.14 & 0.15 & 0.19 & 0.16 \\
\hline 20. Spain & 0.83 & 0.71 & 1.17 & 0.68 & 1.01 & 0.57 & 1.08 & 1.04 & 0.98 & 0.55 & 0.89 & 0.73 \\
\hline 21. Finland & 1.14 & 1.66 & 1.16 & 1.09 & 1.13 & 0.82 & 1.49 & 1.09 & 1.37 & 0.88 & 1.31 & 1.17 \\
\hline 22. NZ & 1.86 & 2.73 & 2.05 & 1.67 & 2.12 & 1.00 & 1.98 & 1.55 & 1.83 & 1.02 & 1.70 & 1.62 \\
\hline 23. Israel & 4.69 & 5.05 & 4.11 & 5.12 & 3.66 & 2.73 & 5.53 & 3.71 & 5.05 & 2.67 & 5.02 & 3.92 \\
\hline 24. Greece & 0.84 & 0.87 & 1.21 & 0.63 & 0.88 & 0.43 & 0.92 & 1.06 & 0.95 & 0.45 & 0.90 & 0.73 \\
\hline 25. Malta & 0.33 & 0.47 & 0.35 & 0.15 & 0.37 & 0.18 & 0.39 & 0.58 & 0.37 & 0.18 & 0.32 & 0.26 \\
\hline 26. Portugal & 0.85 & 0.81 & 0.88 & 0.36 & 0.79 & 0.52 & 1.18 & 1.20 & 0.93 & 0.70 & 0.81 & 0.78 \\
\hline 27. Slovenia & 195.60 & 151.70 & 209.50 & 133.30 & 159.10 & 105.60 & 226.10 & 156.60 & 206.80 & 113.30 & 155.20 & 151.70 \\
\hline 28. Czech & 17.64 & 18.91 & 26.20 & 10.71 & 21.61 & 8.50 & 25.86 & 29.70 & 18.59 & 7.20 & 15.59 & 13.45 \\
\hline 29. Hungary & 0.16 & 0.15 & 0.19 & 0.08 & 0.16 & 0.06 & 0.24 & 0.24 & 0.16 & 0.06 & 0.14 & 0.10 \\
\hline 30. Korea & 1.30 & 0.94 & 0.96 & 1.12 & 0.90 & 0.56 & 0.96 & 0.76 & 0.97 & 0.68 & 0.89 & 0.81 \\
\hline 31. Slovakia & 22.70 & 23.58 & 29.72 & 10.06 & 26.69 & 9.14 & 31.00 & 45.46 & 20.71 & 6.88 & 14.57 & 14.77 \\
\hline 32. Croatia & 5.80 & 5.50 & 5.77 & 1.74 & 4.99 & 2.78 & 7.04 & 6.16 & 5.20 & 2.54 & 5.03 & 3.91 \\
\hline 33. Poland & 2.18 & 3.05 & 3.28 & 1.28 & 2.69 & 1.13 & 3.41 & 5.36 & 2.81 & 0.92 & 2.72 & 1.94 \\
\hline 34. Lithuania & 2.08 & 2.24 & 2.82 & 0.93 & 2.31 & 0.72 & 2.80 & 5.39 & 2.11 & 0.53 & 2.25 & 1.31 \\
\hline 35. Estonia & 11.12 & 10.42 & 14.10 & 6.55 & 10.99 & 4.11 & 12.64 & 13.10 & 10.74 & 2.84 & 11.33 & 7.00 \\
\hline 36. Latvia & 0.38 & 0.38 & 0.45 & 0.19 & 0.41 & 0.13 & 0.47 & 0.76 & 0.36 & 0.10 & 0.40 & 0.25 \\
\hline 37. Mexico & 7.49 & 7.92 & 9.23 & 10.33 & 6.97 & 4.15 & 8.19 & 13.44 & 8.65 & 4.19 & 7.80 & 7.46 \\
\hline 38. Bulgaria & 1.05 & 0.79 & 1.10 & 0.44 & 0.94 & 0.36 & 1.30 & 1.53 & 0.96 & 0.17 & 0.69 & 0.58 \\
\hline 39. Russia & 13.10 & 10.80 & 20.00 & 3.40 & 18.40 & 2.90 & 15.10 & 23.00 & 13.50 & 3.00 & 15.70 & 10.80 \\
\hline 40. Romania & 16.17 & 12.94 & 13.02 & 7.74 & 15.60 & 5.00 & 19.18 & 29.96 & 14.58 & 2.68 & 12.72 & 8.19 \\
\hline 41. Macedonia & 30.00 & 21.30 & 30.00 & 13.60 & 30.60 & 9.40 & 40.50 & 33.30 & 28.70 & 9.30 & 23.20 & 21.20 \\
\hline 42. Turkey & 903.94 & 789.09 & 1029.75 & 385.86 & 856.43 & 364.25 & 1086.31 & 2092.93 & 918.79 & 243.11 & 642.38 & 634.68 \\
\hline
\end{tabular}

Note: Nominal prices are in thousands for Japan, Hungary, Korea, Romania, and Turkey. 
TABLE A3

VOLUME OF CONSUMPTION PER CAPITA OF 12 GOODS IN 42 COUNTRIES

(US dollars)

\begin{tabular}{|c|c|c|c|c|c|c|c|c|c|c|c|c|c|}
\hline $\begin{array}{c}\text { Country } \\
(1)\end{array}$ & $\begin{array}{l}\text { D } \\
8 \\
0 \\
\text { I } \\
(2) \\
\end{array}$ & 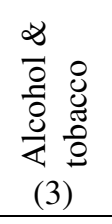 & 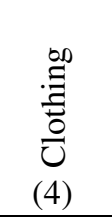 & 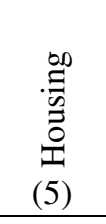 & $\begin{array}{l}\frac{0}{0} \\
\bar{\pi} \\
\tilde{0} \\
0 \\
(6)\end{array}$ & 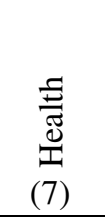 & 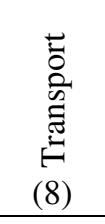 & $\begin{array}{c}\Xi \\
\vdots \\
0 \\
(9)\end{array}$ & 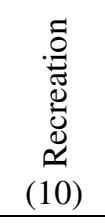 & 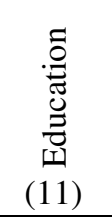 & 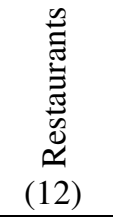 & $\begin{array}{c}\bar{\Xi} \\
\stackrel{\Xi}{0} \\
(13) \\
\end{array}$ & $\begin{array}{c}\underset{\tilde{U}}{0} \\
\stackrel{(14)}{ }\end{array}$ \\
\hline 1. L'bourg & 2,247 & 3,655 & 937 & 4,870 & 1,883 & 2,863 & 4,323 & 547 & 2,211 & 1,738 & 1,812 & 3,173 & 30,258 \\
\hline 2. USA & 1,884 & 560 & 1,273 & 3,900 & 1,180 & 3,121 & 3,384 & 491 & 2,519 & 1,259 & 1,593 & 3,606 & 24,768 \\
\hline 3. UK & 1,550 & 361 & 1,139 & 4,148 & 873 & 2,607 & 1,716 & 319 & 1,945 & 1,313 & 1,611 & 3,317 & 20,899 \\
\hline 4. S'land & 1,670 & 752 & 769 & 3,459 & 886 & 3,000 & 1,298 & 444 & 1,511 & 1,624 & 1,196 & 2,815 & 19,424 \\
\hline 5. Austria & 1,664 & 464 & 896 & 3,694 & 1,152 & 2,387 & 1,524 & 373 & 1,584 & 1,773 & 1,748 & 1,904 & 19,161 \\
\hline 6. Norway & 1,682 & 320 & 798 & 3,923 & 893 & 3,163 & 1,331 & 447 & 1,724 & 1,901 & 670 & 1,839 & 18,691 \\
\hline 7. France & 1,839 & 442 & 644 & 3,196 & 869 & 3,350 & 1,741 & 266 & 1,289 & 1,764 & 1,073 & 1,966 & 18,439 \\
\hline 8. Iceland & 1,955 & 385 & 705 & 3,542 & 868 & 3,444 & 1,278 & 236 & 1,330 & 2,205 & 795 & 1,615 & 18,358 \\
\hline 9. Denmark & 1,522 & 489 & 656 & 3,837 & 778 & 2,387 & 1,060 & 335 & 1,461 & 2,076 & 588 & 2,954 & 18,145 \\
\hline 10. Sweden & 1,474 & 379 & 640 & 3,702 & 534 & 2,655 & 1,182 & 558 & 1,514 & 2,253 & 546 & 2,497 & 17,934 \\
\hline 11. N'lands & 1,527 & 423 & 681 & 2,799 & 920 & 2,615 & 1,205 & 576 & 1,612 & 1,599 & 732 & 3,181 & 17,871 \\
\hline 12. Canada & 1,497 & 389 & 694 & 3,595 & 828 & 2,538 & 2,050 & 442 & 1,478 & 1,357 & 979 & 1,888 & 17,736 \\
\hline 13. Belgium & 1,766 & 518 & 605 & 3,335 & 759 & 2,771 & 1,602 & 258 & 1,261 & 1,951 & 701 & 2,209 & 17,735 \\
\hline 14. Australia & 1,540 & 424 & 527 & 3,002 & 871 & 3,013 & 1,545 & 430 & 1,583 & 1,431 & 1,132 & 1,945 & 17,443 \\
\hline 15. Italy & 1,963 & 360 & 1,131 & 3,454 & 1,163 & 2,275 & 1,391 & 329 & 984 & 1,577 & 1,236 & 1,541 & 17,403 \\
\hline 16. Germany & 1,726 & 620 & 753 & 3,330 & 941 & 2,588 & 1,561 & 403 & 1,284 & 969 & 725 & 2,042 & 16,941 \\
\hline 17. Cyprus & 1,932 & 520 & 900 & 2,739 & 869 & 1,079 & 1,644 & 472 & 1,000 & 1,263 & 1,442 & 2,108 & 15,969 \\
\hline 18. Ireland & 976 & 527 & 961 & 2,407 & 930 & 2,193 & 1,043 & 346 & 909 & 2,054 & 1,836 & 1,783 & 15,965 \\
\hline 19. Japan & 1,339 & 489 & 595 & 2,786 & 607 & 2,863 & 1,438 & 394 & 1,451 & 1,109 & 837 & 1,881 & 15,788 \\
\hline 20. Spain & 2,020 & 469 & 566 & 2,232 & 612 & 2,135 & 1,190 & 273 & 983 & 1,507 & 2,319 & 1,396 & 15,701 \\
\hline 21. Finland & 1,476 & 467 & 522 & 3,076 & 568 & 2,375 & 1,082 & 403 & 1,236 & 1,651 & 651 & 2,088 & 15,596 \\
\hline 22. NZ & 1,428 & 347 & 449 & 2,571 & 577 & 2,201 & 1,358 & 379 & 1,473 & 1,521 & 895 & 1,189 & 14,390 \\
\hline 23. Israel & 1,776 & 233 & 371 & 2,336 & 911 & 2,140 & 808 & 493 & 780 & 2,660 & 342 & 1,509 & 14,358 \\
\hline 24. Greece & 1,762 & 507 & 806 & 2,322 & 683 & 1,940 & 812 & 252 & 591 & 1,426 & 1,800 & 791 & 13,691 \\
\hline 25. Malta & 1,821 & 253 & 566 & 2,063 & 788 & 1,657 & 1,205 & 270 & 889 & 1,598 & 1,417 & 1,144 & 13,669 \\
\hline 26. Portugal & 1,702 & 382 & 628 & 2,303 & 717 & 2,068 & 1,111 & 236 & 681 & 1,211 & 941 & 1,177 & 13,156 \\
\hline 27. Slovenia & 1,308 & 467 & 451 & 2,254 & 585 & 1,902 & 977 & 264 & 788 & 1,337 & 634 & 1,027 & 11,993 \\
\hline 28. Czech & 1,217 & 577 & 252 & 2,637 & 308 & 1,897 & 486 & 126 & 878 & 1,515 & 526 & 811 & 11,229 \\
\hline 29. Hungary & 1,090 & 514 & 210 & 2,088 & 386 & 1,960 & 572 & 197 & 562 & 1,619 & 328 & 852 & 10,381 \\
\hline 30. Korea & 903 & 193 & 371 & 1,118 & 382 & 651 & 934 & 597 & 671 & 1,199 & 654 & 2,044 & 9,717 \\
\hline 31. Slovakia & 1,146 & 275 & 170 & 2,697 & 231 & 1,345 & 351 & 100 & 588 & 1,147 & 604 & 564 & 9,218 \\
\hline 32. Croatia & 1,256 & 319 & 324 & 3,106 & 295 & 783 & 532 & 141 & 302 & 837 & 408 & 616 & 8,918 \\
\hline 33. Poland & 1,243 & 287 & 185 & 2,573 & 224 & 1,174 & 414 & 79 & 368 & 1,281 & 147 & 756 & 8,729 \\
\hline 34. Lithuania & 1,328 & 306 & 209 & 1,796 & 215 & 1,476 & 481 & 59 & 350 & 1,681 & 142 & 537 & 8,581 \\
\hline 35. Estonia & 1,021 & 467 & 227 & 1,882 & 233 & 1,007 & 462 & 117 & 422 & 1,773 & 249 & 514 & 8,374 \\
\hline 36. Latvia & 978 & 304 & 249 & 1,738 & 114 & 1,204 & 293 & 73 & 394 & 1,506 & 179 & 297 & 7,330 \\
\hline 37. Mexico & 1,377 & 142 & 157 & 546 & 510 & 801 & 884 & 52 & 165 & 1,009 & 424 & 688 & 6,756 \\
\hline 38. Bulgaria & 729 & 118 & 99 & 1,539 & 104 & 642 & 353 & 116 & 169 & 1,127 & 370 & 203 & 5,567 \\
\hline 39. Russia & 899 & 297 & 237 & 859 & 108 & 1,214 & 268 & 59 & 157 & 1,021 & 65 & 315 & 5,499 \\
\hline 40. Romania & 1,015 & 196 & 132 & 1,420 & 125 & 736 & 282 & 47 & 177 & 793 & 181 & 231 & 5,336 \\
\hline 41. Macedonia & 1,014 & 175 & 189 & 1,229 & 132 & 852 & 257 & 159 & 95 & 573 & 149 & 300 & 5,123 \\
\hline 42. Turkey & 773 & 136 & 159 & 1,882 & 227 & 282 & 213 & 57 & 76 & 653 & 185 & 237 & 4,882 \\
\hline
\end{tabular}

Note: Totals may not check due to rounding. 
TABLE A4

RELATIVE PPP PRICES FOR 12 COMMODITIES IN 42 COUNTRIES

(Logarithmic ratios $\times 100$ )

\begin{tabular}{|c|c|c|c|c|c|c|c|c|c|c|c|c|}
\hline $\begin{array}{c}\text { Country } \\
\text { (1) }\end{array}$ & $\begin{array}{l}\overline{8} \\
8 \\
1 \\
(2)\end{array}$ & 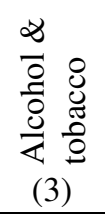 & 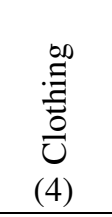 & 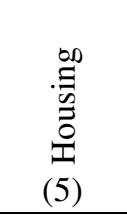 & 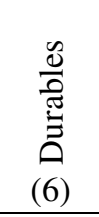 & 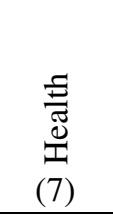 & 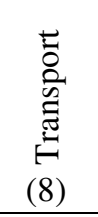 & $\begin{array}{c}\text { घี } \\
\text { ठิ } \\
(9)\end{array}$ & 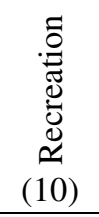 & 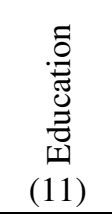 & 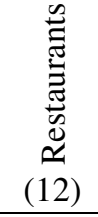 & $\begin{array}{c}\bar{\Xi} \\
\stackrel{\Xi}{0} \\
(13)\end{array}$ \\
\hline 1. L'bourg & 2.1 & -25.5 & 20.5 & 6.4 & 4.1 & -22.5 & 2.2 & -26.0 & 9.9 & 22.4 & -1.0 & -5.2 \\
\hline 2. USA & -19.7 & -12.7 & -20.2 & 1.1 & -9.6 & 31.9 & -29.2 & -15.8 & -20.3 & 48.4 & -18.3 & -7.8 \\
\hline 3. UK & -0.9 & 59.3 & -14.3 & -32.9 & 14.1 & -33.0 & 32.9 & 14.4 & 11.1 & -13.3 & 17.9 & -1.5 \\
\hline 4. S'land & 10.1 & -19.6 & -8.8 & 14.2 & -11.5 & -19.3 & 4.0 & -15.3 & 10.2 & -9.5 & 8.9 & -5.4 \\
\hline 5. Austria & 0.3 & -2.0 & 15.2 & -19.5 & 8.1 & -26.6 & 27.5 & 4.6 & 13.8 & -15.8 & 4.7 & 7.6 \\
\hline 6. Norway & 12.7 & 64.1 & -2.5 & -34.3 & -4.4 & -25.2 & 38.2 & -17.9 & 16.9 & -24.6 & 23.8 & 7.2 \\
\hline 7. France & 11.7 & 8.4 & 3.0 & 9.6 & -0.6 & -36.5 & 19.3 & 21.5 & 12.2 & -35.6 & 1.3 & -0.9 \\
\hline 8. Iceland & 22.6 & 50.9 & 6.2 & -29.6 & 8.0 & -32.2 & 18.3 & -43.3 & 28.7 & -35.8 & 35.9 & 0.0 \\
\hline 9. Denmark & 3.8 & 13.7 & -2.7 & -5.7 & -5.7 & -27.8 & 35.8 & -23.7 & 11.2 & -18.0 & 15.6 & 5.5 \\
\hline 10. Sweden & 3.9 & 28.5 & 7.7 & -5.7 & 13.9 & -29.2 & 28.9 & -33.7 & 16.1 & -24.2 & 12.9 & 6.7 \\
\hline 11. N'lands & 0.0 & 0.4 & 18.1 & 4.8 & 7.1 & -36.1 & 32.0 & -4.0 & 4.8 & -24.7 & 7.2 & -1.3 \\
\hline 12. Canada & -6.1 & 39.2 & 6.8 & -5.7 & 13.5 & -18.2 & 3.6 & -30.9 & 13.7 & 2.1 & 9.1 & -4.1 \\
\hline 13. Belgium & 3.7 & -1.1 & 21.9 & -4.1 & 2.6 & -24.7 & 19.0 & 18.1 & 10.5 & -17.0 & 5.4 & 3.7 \\
\hline 14. Australia & 2.5 & 41.4 & 10.4 & 2.3 & 3.4 & -36.2 & 11.6 & -4.2 & 14.2 & -20.7 & 3.1 & 2.6 \\
\hline 15. Italy & 6.4 & -4.4 & 15.3 & -19.8 & 9.5 & -19.2 & 20.4 & 27.8 & 17.4 & -26.9 & 12.2 & -2.6 \\
\hline 16. Germany & -4.1 & -12.6 & 9.8 & 0.9 & -2.6 & -20.5 & 22.9 & -4.9 & 7.1 & 0.1 & -11.6 & 1.2 \\
\hline 17. Cyprus & 9.1 & 24.5 & 9.5 & -40.0 & 5.8 & -25.5 & 23.3 & -33.1 & 15.7 & -27.8 & 23.3 & -14.7 \\
\hline 18. Ireland & 0.4 & 42.8 & -23.1 & 11.4 & -5.5 & -37.0 & 21.8 & -5.1 & 6.0 & -28.7 & 16.2 & -6.1 \\
\hline 19. Japan & 34.5 & -25.0 & 1.8 & 19.4 & -7.2 & -41.6 & -5.2 & -10.4 & -17.2 & -12.2 & 13.6 & -5.1 \\
\hline 20. Spain & 2.3 & -14.3 & 36.5 & -17.7 & 21.3 & -35.9 & 27.9 & 24.2 & 18.6 & -38.8 & 8.4 & -11.3 \\
\hline 21. Finland & 0.2 & 37.4 & 1.4 & -4.5 & -1.4 & -32.9 & 26.4 & -5.0 & 18.1 & -25.8 & 13.8 & 2.0 \\
\hline 22. NZ & 10.8 & 49.2 & 20.7 & 0.3 & 24.2 & -51.5 & 17.0 & -7.4 & 9.4 & -49.2 & 2.1 & -2.9 \\
\hline 23. Israel & 13.0 & 20.4 & -0.4 & 21.7 & -11.8 & -41.2 & 29.4 & -10.4 & 20.3 & -43.3 & 19.8 & -5.1 \\
\hline 24. Greece & 7.2 & 11.4 & 43.4 & -21.1 & 11.9 & -60.2 & 16.9 & 30.8 & 19.9 & -54.5 & 14.3 & -7.3 \\
\hline 25. Malta & 11.7 & 45.8 & 14.5 & -71.3 & 21.5 & -51.9 & 26.0 & 66.7 & 22.5 & -51.0 & 8.2 & -14.1 \\
\hline 26. Portugal & 9.8 & 5.8 & 13.3 & -74.5 & 2.5 & -38.6 & 42.9 & 44.7 & 19.6 & -9.0 & 5.0 & 2.0 \\
\hline 27. Slovenia & 20.7 & -4.7 & 27.6 & -17.6 & 0.0 & -40.9 & 35.3 & -1.5 & 26.3 & -33.8 & -2.4 & -4.7 \\
\hline 28. Czech & 17.9 & 24.8 & 57.4 & -32.0 & 38.2 & -55.1 & 56.1 & 70.0 & 23.1 & -71.8 & 5.5 & -9.3 \\
\hline 29. Hungary & 25.1 & 19.5 & 44.5 & -45.0 & 25.8 & -64.8 & 66.6 & 66.0 & 25.0 & -79.9 & 10.3 & -15.7 \\
\hline 30. Korea & 34.4 & 2.5 & 4.5 & 19.8 & -1.9 & -50.4 & 4.5 & -18.4 & 5.9 & -29.8 & -3.5 & -12.9 \\
\hline 31. Slovakia & 31.0 & 34.8 & 57.9 & -50.3 & 47.2 & -59.9 & 62.2 & 100.4 & 21.9 & -88.4 & -13.3 & -12.0 \\
\hline 32. Croatia & 33.0 & 27.9 & 32.6 & -87.6 & 18.1 & -40.6 & 52.5 & 39.0 & 22.2 & -49.4 & 18.8 & -6.4 \\
\hline 33. Poland & 11.7 & 45.1 & 52.6 & -41.8 & 32.6 & -53.9 & 56.4 & 101.7 & 37.0 & -75.2 & 33.7 & 0.0 \\
\hline 34. Lithuania & 25.8 & 33.2 & 56.2 & -54.8 & 36.4 & -80.5 & 55.5 & 121.2 & 27.5 & -110.3 & 33.9 & -20.3 \\
\hline 35. Estonia & 29.0 & 22.4 & 52.7 & -24.0 & 27.6 & -70.7 & 41.8 & 45.0 & 25.4 & -107.5 & 30.8 & -17.3 \\
\hline 36. Latvia & 31.6 & 31.4 & 48.4 & -39.8 & 37.7 & -79.8 & 52.1 & 99.1 & 25.1 & -101.1 & 34.7 & -11.1 \\
\hline 37. Mexico & 2.4 & 8.0 & 23.2 & 34.5 & -4.8 & -56.6 & 11.3 & 60.8 & 16.7 & -55.7 & 6.4 & 1.9 \\
\hline 38. Bulgaria & 37.1 & 8.4 & 41.9 & -48.7 & 25.8 & -69.1 & 58.7 & 74.5 & 28.1 & -147.3 & -4.9 & -21.9 \\
\hline 39. Russia & 25.2 & 5.7 & 66.9 & -109.7 & 58.7 & -124.8 & 38.9 & 81.2 & 28.2 & -123.2 & 43.1 & 5.7 \\
\hline 40. Romania & 33.1 & 10.8 & 11.4 & -40.5 & 29.5 & -84.3 & 50.2 & 94.8 & 22.7 & -146.7 & 9.1 & -34.9 \\
\hline 41. Macedonia & 28.9 & -5.4 & 29.0 & -50.2 & 30.8 & -86.9 & 58.7 & 39.1 & 24.2 & -88.8 & 3.1 & -5.6 \\
\hline 42. Turkey & 30.7 & 17.1 & 43.7 & -54.4 & 25.3 & -60.2 & 49.1 & 114.7 & 32.3 & -100.6 & -3.5 & -4.7 \\
\hline
\end{tabular}


TABLE A5

\section{CONSUMPTION AND GDP PER CAPITA IN 42 COUNTRIES}

\begin{tabular}{|c|c|c|c|c|c|}
\hline \multirow[t]{3}{*}{ Country } & \multirow{3}{*}{$\begin{array}{l}\text { Consumption per capita } \\
\text { (US dollars) }\end{array}$} & \multicolumn{4}{|c|}{ GDP per capita } \\
\hline & & \multicolumn{2}{|c|}{ Using PPP } & \multicolumn{2}{|c|}{ Using market exchange rates } \\
\hline & & $\begin{array}{c}\text { US dollars } \\
\text { (3) }\end{array}$ & $\begin{array}{c}\text { Index } \\
(\text { L'bourg }=100) \\
(4)\end{array}$ & $\begin{array}{l}\text { US dollars } \\
\text { (5) }\end{array}$ & $\begin{array}{c}\text { Index } \\
\left(L^{\prime} \text { bourg }=100\right) \\
(6)\end{array}$ \\
\hline 1. L'bourg & 30,258 & 47,271 & 100.0 & 48,104 & 100.0 \\
\hline 2. USA & 24,768 & 32,798 & 69.4 & 36,202 & 75.3 \\
\hline 3. UK & 20,899 & 26,188 & 55.4 & 26,393 & 54.9 \\
\hline 4. S'land & 19,424 & 29,449 & 62.3 & 37,624 & 78.2 \\
\hline 5. Austria & 19,161 & 27,270 & 57.7 & 25,818 & 53.7 \\
\hline 6. Norway & 18,691 & 33,232 & 70.3 & 42,035 & 87.4 \\
\hline 7. France & 18,439 & 25,096 & 53.1 & 23,455 & 48.8 \\
\hline 8. Iceland & 18,358 & 26,594 & 56.3 & 29,550 & 61.4 \\
\hline 9. Denmark & 18,145 & 27,217 & 57.6 & 32,059 & 66.6 \\
\hline 10. Sweden & 17,934 & 25,504 & 54.0 & 27,084 & 56.3 \\
\hline 11. N'lands & 17,871 & 27,123 & 57.4 & 25,935 & 53.9 \\
\hline 12. Canada & 17,736 & 26,807 & 56.7 & 23,176 & 48.2 \\
\hline 13. Belgium & 17,735 & 25,938 & 54.9 & 23,780 & 49.4 \\
\hline 14. Australia & 17,443 & 25,276 & 53.5 & 20,255 & 42.1 \\
\hline 15. Italy & 17,403 & 24,219 & 51.2 & 20,745 & 43.1 \\
\hline 16. Germany & 16,941 & 24,148 & 51.1 & 24,034 & 50.0 \\
\hline 17. Cyprus & 15,969 & 18,556 & 39.3 & 14,677 & 30.5 \\
\hline 18. Ireland & 15,965 & 29,789 & 63.0 & 30,993 & 64.4 \\
\hline 19. Japan & 15,788 & 24,648 & 52.1 & 31,170 & 64.8 \\
\hline 20. Spain & 15,701 & 21,014 & 44.5 & 16,208 & 33.7 \\
\hline 21. Finland & 15,596 & 25,192 & 53.3 & 25,287 & 52.6 \\
\hline 22. NZ & 14,390 & 19,875 & 42.0 & 14,874 & 30.9 \\
\hline 23. Israel & 14,358 & 20,490 & 43.3 & 16,529 & 34.4 \\
\hline 24. Greece & 13,691 & 17,275 & 36.5 & 12,157 & 25.3 \\
\hline 25. Malta & 13,669 & 16,500 & 34.9 & 10,270 & 21.3 \\
\hline 26. Portugal & 13,156 & 17,069 & 36.1 & 11,668 & 24.3 \\
\hline 27. Slovenia & 11,993 & 16,729 & 35.4 & 11,095 & 23.1 \\
\hline 28. Czech & 11,229 & 15,025 & 31.8 & 7,232 & 15.0 \\
\hline 29. Hungary & 10,381 & 13,013 & 27.5 & 6,383 & 13.3 \\
\hline 30. Korea & 9,717 & 16,709 & 35.3 & 11,481 & 23.9 \\
\hline 31. Slovakia & 9,218 & 11,418 & 24.2 & 4,503 & 9.4 \\
\hline 32. Croatia & 8,918 & 9,583 & 20.3 & 5,046 & 10.5 \\
\hline 33. Poland & 8,729 & 10,141 & 21.5 & 4,985 & 10.4 \\
\hline 34. Lithuania & 8,581 & 9,421 & 19.9 & 4,050 & 8.4 \\
\hline 35. Estonia & 8,374 & 10,195 & 21.6 & 5,164 & 10.7 \\
\hline 36. Latvia & 7,330 & 8,655 & 18.3 & 3,939 & 8.2 \\
\hline 37. Mexico & 6,756 & 8,489 & 18.0 & 6,390 & 13.3 \\
\hline 38. Bulgaria & 5,567 & 6,400 & 13.5 & 1,984 & 4.1 \\
\hline 39. Russia & 5,499 & 7,327 & 15.5 & 2,392 & 5.0 \\
\hline 40. Romania & 5,336 & 6,357 & 13.4 & 2,089 & 4.3 \\
\hline 41. Macedonia & 5,123 & 5,464 & 11.6 & 1,877 & 3.9 \\
\hline 42. Turkey & 4,882 & 5,903 & 12.5 & 2,605 & 5.4 \\
\hline
\end{tabular}


